Loma Linda University

TheScholarsRepository@LLU: Digital Archive of Research, Scholarship \& Creative Works

Loma Linda University Electronic Theses, Dissertations \& Projects

6-1977

\title{
The Effect of Carbon Dioxide Concentration on Calcification in the Red Coralline Alga BOSSIELLA ORBIGNIANA
}

\author{
A. Dwight Smith
}

Follow this and additional works at: https://scholarsrepository.llu.edu/etd

Part of the Biology Commons, and the Botany Commons

\section{Recommended Citation}

Smith, A. Dwight, "The Effect of Carbon Dioxide Concentration on Calcification in the Red Coralline Alga BOSSIELLA ORBIGNIANA" (1977). Loma Linda University Electronic Theses, Dissertations \& Projects. 947. https://scholarsrepository.llu.edu/etd/947

This Dissertation is brought to you for free and open access by TheScholarsRepository@LLU: Digital Archive of Research, Scholarship \& Creative Works. It has been accepted for inclusion in Loma Linda University Electronic Theses, Dissertations \& Projects by an authorized administrator of TheScholarsRepository@LLU: Digital Archive of Research, Scholarship \& Creative Works. For more information, please contact scholarsrepository@llu.edu. 


\section{Abstract \\ THE EFFECT OF CARBON DIOXIDE CONCENTRATION \\ ON CALCIFICATION IN THE \\ RED CORALLINE ALGA BOSSIELLA ORBIGNIANA}

by A. Dwight Smith

The relationship between various experimental concentrations of $\mathrm{CO}_{2}$ and calcification was studied by measuring $\mathrm{Ca}-45$ incorporation into the crystalline matrix. Air containing $\mathrm{CO}_{2}$ at partiai pressures $\left(\mathrm{P}_{\mathrm{CO}_{2}}\right)$ of $0.04 \%$ to $5.5 \%$ was bubbled through synthetic sea water in incubation vessels. The resultant $\mathrm{pH}$ values ranged from 8.7 to 6.5 . The relative concentrations of $\mathrm{CO}_{2}, \mathrm{HCO}_{3}^{-}$, and $\mathrm{CO}_{3}^{2-}$ were calculated from the measured $\mathrm{pH}-\mathrm{P}_{2}$ combinations. Calcification was correlated positively with $\mathrm{HCO}_{3}{ }^{-}$ expressed as percent of total carbon. Maximum calcification of about one-third above normal occurred between $0.1 \%$ and $1.0 \% \mathrm{P}_{\mathrm{CO}_{2}}$. At $0.26 \%$ $\mathrm{P}_{\mathrm{CO}_{2}}$, calcification increased as increments of $\mathrm{NaHCO}_{3}$ in the range from 1 to $8 \mathrm{mM}$ were added; this increase did not occur in the killed controls. The data suggest that calcification is controlled by a biological process that may be sensitive to $\mathrm{pH}$ and/or to the $\mathrm{HCO}_{3}^{-}$concentration. The data also suggest that an increase in $\mathrm{CO}_{2}$ over the present atmospheric level would significantly increase calcification in this marine alga. 


\title{
LOMA LINDA UNIVERSITY \\ Graduate School
}

\section{THE EFFECT OF CARBON DIOXIDE CONCENTRATION \\ ON CALCIFICATION IN THE \\ RED CORALLINE ALGA BOSSIELLA ORBIGNIANA}

by

A. Dwight Smith

\author{
A Dissertation in Partial Fulfillment \\ of the Requirements for the Degree Doctor of Philosophy \\ in the Field of Biology
}

June 1977 
Each person whose signature appears below certifies that this dissertation in his opinion is adequate, in scope and quality, as a dissertation for the degree Doctor of Philosophy.
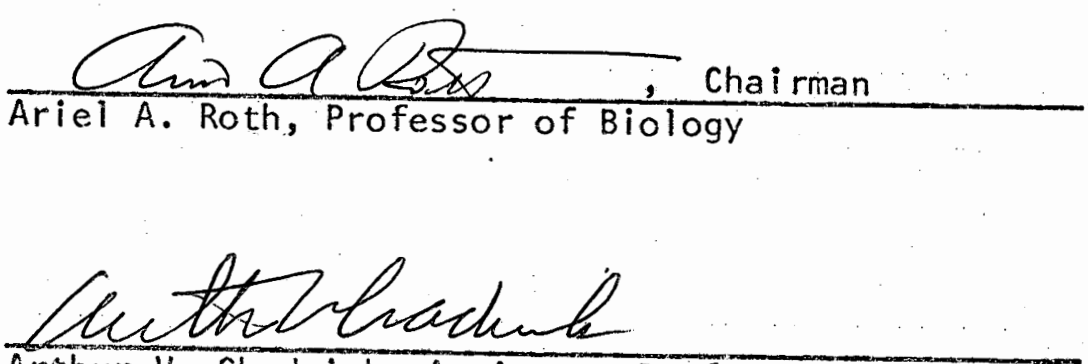

Arthur V. Chadwick, Assistant Professor of Biology

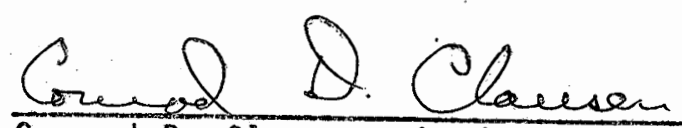

Conrad D. Clausen, Assistant Professor of Biology

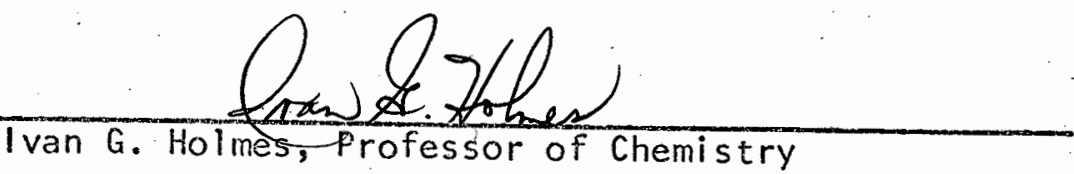

\section{Elured 8.mceluskey}

Elwood S. McCluskey, Associate Professor of Biology 
To my Christian teachers, whose exemplary lives have encouraged me to pursue research that reveals the beauty in God's created works and glorifies His name, I dedicate this work. 


\section{ACKNOWLEDGMENTS}

Appreciation is due to my guidance committee Drs. Ariel Roth, Conrad Clausen, Elwood McCluskey, Arthur Chadwick, and Ivan Holmes who all took an interest in my project and contributed significantly. A number of other individuals who contributed ideas and encouragement as the project developed are Drs. Clarence Collier, Anthony Zuccarelli, Charles Slattery, Barry Taylor, Ian Fraser, Clyde Webster, Irwin Ting, and Roy Young. Dr. Alan Pressler analyzed the tanks of gas and Dr. Fred Riley analyzed the bleach for the presence of calcium. Dr. Paul Yahiku furnished statistical counseling. Assistance with computer programing came from Dr. Duane Zimmerman, George Johnston, and Bill Hughes. Carol Logan took the pictures for Figures 1 and 2 and Joy Chadwick went beyond the call of duty to have the rest of the figures ready for the deadline. Diving assistance came from three of my children Jon, Lyla, and Susan. Manuscript typing was done by Marilyn Gregg, Karen Niederman, and Kathy Ching. I especially wish to thank Marilyn for her unselfish dedication and long hard hours spent in meeting the final deadline.

The management of Treasure Island Trailer Park was kind enough to grant us direct access to the collecting site, an act that saved us many hours of extra work during the course of the research.

Financial aid came from the Loma Linda University Biology Department, Graduate Research Society, and the Geoscience Research Institute. Computation assistance was received from the Loma Linda University Scientific Computation Facility supported in part by NIH Grant RR0027-10 and from the Loma Linda University Data Processing Center. 
Last, but not least, I wish to recognize the invaluable advice and counsel received from my wife, Ruth, who has put up with me for better. and/or worse during this period when I could do nothing but "talk algae and $\mathrm{CO}_{2}$ " 
INTRODUCTION . . . . . . . . . . . . . . . . . . 1

MATERIALS AND METHODS . . . . . . . . . . . . . . . . . 6

RESULTS . . . . . . . . . . . . . . . . . . 12

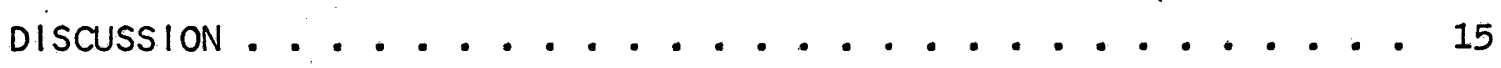

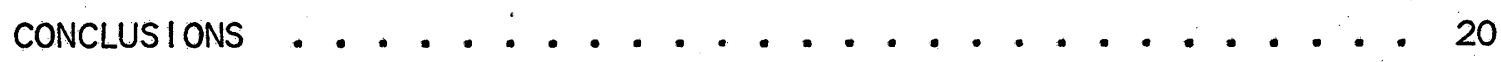

TABLES . . . . . . . . . . . . . . . . . . . . 22

FIGURES . . . . . . . . . . . . . . . . . . . . . . 31

LITERATURE CITED . . . . . . . . . . . . . . . . . 45

APPENDIX . . . . . . . . . . . . . . . . . . 49 


\section{LIST OF TABLES}

Table

Page

1 Experimental parameters (in hrs and min)........ 22

2 Beginning and ending pH values of Experiments $s-1$ to $s-10$. . . . . . . . . . . . . . 23

3 Parameters used for calculation of carbon species concentration ............. 24

4 Light intensity and calcification . . . . . . . . . 25

5 Calcification in Experiments $s-1$ to $s-10$....... 26

6 Correlation coefficients comparing calcification with $\mathrm{HCO}_{3}$ expressed as percent of total carbon . . . . 27 .

7 Calcification results and $\mathrm{pH}$ values for experiments

in which $\mathrm{NaHCO}_{3}$ or $\mathrm{Na}_{2} \mathrm{CO}_{3}$ were added to the sea water . . 28

8 Effect of buffers on calcification . . . . . . . . 29

9 Analyses of variance of data . . . . . . . . . 30 


\section{LIST OF FIGURES}

Figure

Page

1 Plexiglass chamber with plants in sea water . . . . . 32

2 General view of experimental apparatus . . . . . . . 34

3 Relation between $\mathrm{P}_{\mathrm{CO}_{2}}$ and $\mathrm{pH}$. . . . . . . . 36

4 Carbon species expressed as per cent of total carbon . . . 38

5 Calcification as a function of area of

terminal segment ............... . 40

6 Calcification in Bossiella orbigniana as a function

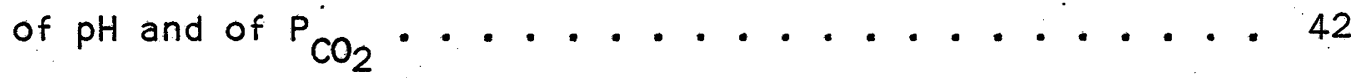

7 Effect on calcification of adding $\mathrm{NaHCO}_{3}$ or $\mathrm{Na}_{2} \mathrm{CO}_{3}$

to the sea water ................ 44 


\section{INTRODUCTION}

Much concern has been expressed about the possible effects of increasing carbon dioxide concentration in the atmosphere. This build up of $\mathrm{CO}_{2}$ is apparently due to increasing use of fossil fuels (Suess, 1973) and other human activities (Adams, Mantovani, and Lundell, 1977; Bolin, 1977). An increase in atmospheric $\mathrm{CO}_{2}$ to ten times that of present. levels is projected if all fossil fuel reserves are consumed (PIass, 1956; Coyne, 1975). According to Coyne (1975) plants and animals could survive in this atmosphere, but "the effect of the extra $\mathrm{CO}_{2}$ on weather cycles and the buffering system in natural waters and thus on the concentration of $\mathrm{pH}$ dependent chemical species is a largely unanswered question." Plass (1956) states that an increase in atmospheric $\mathrm{CO}_{2}$ to 50 times current levels would not change oceanic pH more than half a unit, a level that would be tolerated by marine organisms. The possible influence of carbon dioxide concentration on temperature has given support to the theory that changing $\mathrm{CO}_{2}$ levels in the atmosphere determine long-term changes in the climate (Plass, 1956; Garrels, Lerman, Mackenzie, 1976). The enhancement of photosynthesis with increasing $\mathrm{CO}_{2}$ concentrations (Bolin, 1977) supports the suggestion that the large amounts of organic carbon buried in the earth indicate greater environmental $\mathrm{CO}_{2}$ levels in the past (Plass, 1956). Consistent with this is the common practice of elevating $\mathrm{CO}_{2}$ levels in greenhouses to enhance crop production IMoss, 1976).

The effect of increasing atmospheric levels of $\mathrm{CO}_{2}$ on calcification in marine organisms is not so well known. An optimum pH of 7.8 was found for the division rate of a calcifying unicellular coccolithophorid 
using a medium buffered with the $\mathrm{CO}_{2}$ - bicarbonate - carbonate system (Swift and Taylor, 1966). Calcification in Halimeda, an important green alga associated with tropical reefs (Goreau, 1963), was increased by bubbling $5 \% \mathrm{CO}_{2}$ in air through sea water 1 Stark, Almodovar and Krauss, 1969). Both calcification and photosynthesis rates in Halimeda were increased by increasing the $\mathrm{CO}_{2}$ concentration through the use of several different buffers and increments of $\mathrm{NaHCO}_{3}$ in acidified sea water (Borowitzka and Larkum, 1976b).

- Changing $\mathrm{CO}_{2}$ concentration might also have an effect on the upward rate of growth of reef structures, a subject that has been of interest to both biologists and geologists, especially since Darwin (1842) put forward his subsidence theory for the origin of atolls (stoddart, 1969 ). Although most reefs are relatively shallow, Eniwetok Atoll is interpreted as being a reef that is over 1400 meters thick. If this is so, theories of reef development must account for an accumulation of this magnitude. That ecological factors were not always favorable for reef development 'is suggested by the occurrence of guyots (flat-topped seamounts) and drowned atolls (some of which are located very close to living reefs), commonly at a depth of 1000-2000 meters in the Indo-Pacific Basin (Menard, 1964). Standard estimates for upward growth of coral reefs average about $1 \mathrm{~cm} \mathrm{yr}^{-1}$ (Clausen, 1972). However, Smith (1973) in referring to the Eniwetok windward reef flat states that "there has been virtually no net $\mathrm{CaCO}_{3}$ accumulation over the last several thousand years." A later paper, based on production rates of several shallow seaward reef flat environments (Smith and Kinsey, 1976), suggests "an upper limit of 3 to $5 \mathrm{~mm} \mathrm{yr}^{-1}$ on the potential of modern reef communities to create a 
significant vertical structure on a rising sea." This assumes present environmental conditions.

Because of its fundamental nature the process of calcification has received much attention; yet it is still not understood. The high degree of specificity and organization seen in the end products of calcification, such as the coccoliths of coccolithophorids, tests of foraminifers, and the crystalline matrix of molluscs and coralline algae, strongly suggest that enzymatic control and genetic regulation are involved; it is not just a simple precipitation event.

The differing light and dark calcification rates of corals lsome of which calcify nine times faster in the light than in the dark (Goreau, $19591)$ and of calcareous algae have been used as evidence that light or light produced substances are necessary for calcification (Goreau, 1963). However, there are claims that some photosynthetic organisms calcify faster in the dark (Goreau, 1963); and many non-photosynthetic organisms such as molluscs and vertebrates also carry on calcification, showing that the process does not have to be directly dependent on photosynthesis.

The photosynthetic inhibitor DCMU reversibly inhibits light-enhanced coral calcification without affecting other behavioral events (Vandermeulen, Davis, and Muscatine, 19721; and DCMU inhibits equally both photosynthesis and coccolith formation (Crenshaw, 1964). This is taken as evidence that light enhanced calcification is due largely to photosynthesis and not to some other photobiological event. However, Paasche (1964, 1965), using another coccolithophorid, found that CMU lanother inhibitor of photosynthetic non-cyclic electron flow) was less inhibitory to coccolith formation than to carbon fixation or oxygen evolution. 
Much of the work on algal calcification has involved coccolithophorids (see reviews of Wilbur, Colin vaux and Watabe, 1969; Paasche, 1968; and Darley, 1974) and the green alga Halimeda (Stark, Almodovar, and Krauss, 1969; Borowitzka and Larkum, 1976a, b, c, 1977a, b). A review in press (Borowitzka and Larkum, 1977b) summarizes much of the data in this field.

Crenshaw (1964) concluded that the calcium carbonate portion of the coccolith is formed by photosynthetic fixation of molecular carbon dioxide from bicarbonate assimilated from the medium. According to this view calcite is then precipitated on the preformed matrix which acts as a nucleation site. The equation would be $2 \mathrm{HCO}_{3}^{-}+\mathrm{Ca}^{++} \rightleftharpoons \mathrm{CO}_{2}+\mathrm{CaCO}_{3}+\mathrm{H}_{2} \mathrm{O}$.

Both anatomical and physiological evidence are used by Borowitzka and Larkum (1974, 1976a, b, c and 1977a) to describe the calcification process in Halimeda. They suggest that before calcification begins chloroplasts must reach functional maturity; and the peripheral utricles must fuse together to create an intercellular space that is separated from the external sea water and could be maintained at a higher pH. Calcification begins in the (pilose) cell wall layer facing into this intercellular space. Only the initial nucleation of aragonite is associated with the pilose cell wall layer. Apparently later deposition of aragonite involves precipitation around existing aragonite needles.

Considerable information has been compiled regarding the chemistry of the sea (Harvey, 1957; Riley and Skirrow, 1966, 1975). The distribution of the carbonate system can be represented by $\mathrm{CO}_{2}+\mathrm{H}_{2} \mathrm{O}_{2} \rightleftharpoons \mathrm{H}_{2} \mathrm{CO}_{3} \rightleftharpoons \mathrm{H}^{+}+\mathrm{HCO}_{3}^{-}$ $\rightleftharpoons^{+}+\mathrm{CO}_{3}{ }^{2-}$. The relative amount of each species depends on the $\mathrm{pH}$, salinity and temperature of the sea water. In normal sea water about 1\% of the total $\mathrm{CO}_{2}$ exists as free $\mathrm{CO}_{2}, 9 \%$ as $\mathrm{CO}_{3}^{2-}$, and $90 \%$ as $\mathrm{HCO}_{3}^{-}$ 
(Steemann Nielsen, 1975). The concentration of $\mathrm{CO}_{3}^{2-}$ increases as $\mathrm{pH}$ increases and that of free $\mathrm{CO}_{2}$ increases as $\mathrm{pH}$ decreases. At a $\mathrm{pH}$ slightly above 9, approximately half of the total carbon is $\mathrm{HCO}_{3}^{-}$and half is $\mathrm{CO}_{3}^{2-}$. A knowledge of the distribution of these carbon species is essential in determining their availability for photosynthesis, respiration, and calcification.

Either an open system or a closed'system may be used for laboratory studies. In an open system $\mathrm{CO}_{2}$ of known concentration is bubbled through the sea water until equilibrium is reached and then the distribution of carbon species determined by methods described by Park (1969). In the currently more popular closed system, sea water is acidified and then adjusted to the desired $\mathrm{pH}$ by adding $\mathrm{NaHCO}_{3}$ or $\mathrm{Na}_{2} \mathrm{CO}_{3}$. Organic buffers are also used to keep the medium at a desired $\mathrm{pH}$.

For this study I have used an open system because 1 feel that this more closely simulates the natural system when changing the concentration of $\mathrm{CO}_{2}$ to represent atmospheric conditions that may have existed in the past or may exist in the future. The carbon dioxide-bicarbonatecarbonate system also acts as its own natural buffer system and 1 do not have to determine the effects of added artificial buffers, acid, or base. A coralline alga was chosen because (1) considerably less is known about it, (2) it is found locally, (3) Pearse (1972) has shown that it calcifies at rates similar to a closely related tropical reef species, and (4) Thomas (1976) has elucidated its response to temperature change. 


\section{MATERIALS AND METHODS}

\section{Collection and maintenance}

Plants of the red coralline alga Bossiella orbianiana (Descaisne) Silva (1957) (Corallinaceae) (determined by H. W. Johansen) were collected subtidally between July 4, 1976 and March 21, 1977 near Treasure Island (= Goff $|\mathrm{s}|$ and) about $2 \mathrm{~km}$ south of Laguna Beach, California. The algae were transported in natural sea water of $\mathrm{pH} 8.1$ to 8.3 and kept in an insulated container until needed. See Table 1.

\section{Sea water system}

Six plexiglass chambers measuring $12 \mathrm{~cm} \times 14 \mathrm{~cm} \times 9 \mathrm{~cm}$ high (Fig. 1) were each filled with one liter of synthetic sea water IInstant ocean Synthetic Sea Salts, Aquarium Systems, Inc., Wickliffe, Ohiol. After aeration with normal air, and without plants, the $\mathrm{pH}$ of this sea water was 8.3 to 8.4 . The experimental set-up is pictured in Fig. 2.

\section{Requlation of $\mathrm{P}_{\mathrm{CO}_{2}}$ and $\mathrm{pH}$.measurement}

The partial pressure of $\mathrm{CO}_{2}\left(\mathrm{P}_{\mathrm{CO}_{2}}\right)$ in each chamber was adjusted by bubbling premixed $\mathrm{CO}_{2}$ in air at a flow of $700-1000 \mathrm{ml} \mathrm{min}^{-1}$ into the chamber (except Experiment $\mathrm{s}-10,1500 \mathrm{ml} \mathrm{min}^{-1}$ ).

The tank $\mathrm{P}_{\mathrm{CO}_{2}}$ levels as determined by mass spectrometer analysis expressed as percent of $\mathrm{CO}_{2}$ in air were $0.04,0.11,0.23,0.26,0.39$, $0.93,1.05,2.26$ and 5.46. The relationship between $\mathrm{pH}$ and $\mathrm{P}_{\mathrm{CO}_{2}}$ for our synthetic sea water was obtained by bubbling each gas mixture through sea water to which no plants had been added until the $\mathrm{pH}$ remained stable for several minutes. Since small changes in $\mathrm{pH}$ markedly affect calculations using $\mathrm{pH}$ and $\mathrm{P}_{\mathrm{CO}_{2}}$ (Skirrow, 1975), a least-squares line (Fig. 3) was 
fitted to the measured $\mathrm{pH}-\mathrm{P}_{\mathrm{CO}_{2}}$ points, and $\mathrm{pH}-\mathrm{P} \mathrm{CO}_{2}$ combinations derived from the line were used for further calculations.

The $\mathrm{pH}$ for each chamber was measured with a Corning Model $112 \mathrm{pH}$ meter equipped with a semi-micro combination electrode. Van Lab 7.00 and 10.00 buffers of Hepes and Tris buffers prepared in synthetic sea water were used to calibrate the electrodes. The beginning and ending $\mathrm{pH}$ values for each chamber are given in Table 2. The maximum variation (0.07 to $0.31 \mathrm{pH}$ units) occurred when the $0.04 \% \mathrm{CO}_{2}$ in air was bubbled through the sea water. At other concentrations of $\mathrm{CO}_{2}$ drift was nearly always negative and less than $-0.15 \mathrm{pH}$ units.

\section{Distribution of carbon species in sea water}

The relative concentrations of the various carbon species in synthetic sea water are shown in Fig. 4. The parameters used for the calculations are given in Table 3 and the measured $\mathrm{pH}^{-\mathrm{P}} \mathrm{CO}_{2}$ values were derived as explained in the previous section above. The assumption is made that the constants are $\mathrm{pH}$ independent (Pytkowitz, Ingle, and Mehrbach, 1974l.

\section{Factors that affect the $\mathrm{CO}_{2}$ equilibrium in sea water}

The addition of $\mathrm{CO}_{2}$ or its salt $\left(\mathrm{NaHCO}_{3}, \mathrm{Na}_{2} \mathrm{CO}_{3}\right.$, etc. $)$ disturbs the equilibrium of synthetic sea water; as seen in Figure 4, and changes the $\mathrm{pH}$ as well as the concentrations of the various carbon species. The bubbling of normal air or $\mathrm{CO}_{2}$-enriched air hastens return to a new equilibrium. The new equilibrium will depend on:

(1) the $\mathrm{P}_{\mathrm{CO}_{2}}$ of the prevailing atmosphere 
(2) the degree of saturation of the sea water by $\mathrm{CO}_{2}$; in my case, by the $\mathrm{P}_{\mathrm{CO}_{2}}$ of the $\mathrm{CO}_{2}$-enriched air, as well as by its flow rate (since it is an open system with plants)

(3) salinity of the new concentrations of the various ions, especially $\mathrm{Na}^{+}$and $\mathrm{Mg}^{++}$

(4) the $\mathrm{H}^{+}$activity (measured as $\mathrm{pH}$ )

(5) the activity of the living organisms

(6) temperature

The solubility of $\mathrm{CaCO}_{3}$ and the concentrations of $\mathrm{H}^{+}, \mathrm{CO}_{2}, \mathrm{HCO}_{3}^{-}$, and $\mathrm{CO}_{3}^{2-}$ will all change each time a shift in equilibrium occurs.

Temperature and light

The room temperature remained below $13^{\circ} \mathrm{C}$. Sea water temperature of $19 \pm 0.5^{\circ} \mathrm{C}$ (Thomas, 1976) was regulated using contact thermometers, two 100-watt immersion heaters per chamber, and thermoregulator relays. Two 110-watt high-output cool-white fluorescent lamps directly above the chambers provided $5 \mathrm{~mW} \mathrm{~cm} \mathrm{~cm}^{-2}$ illumination at plant levels.

A comparison (Table 4 ) between plants held overnight in the dark before being used (Experiment $L-1$ ) and those collected on the day of the experiment (Experiment $L-2$ ) suggests that the previous history may affect rate of $\mathrm{Ca}-45$ uptake and that experiments should be conducted as soon after collection as possible for optimum results (see also Roth, 1974; Thomas, 1976). Table 4 also suggests that the light intensity of $5 \mathrm{~mW} \mathrm{~cm}^{-2}$ (see arrow) used for the standard experiments was not a limiting factor.

\section{Preparation of plants and incubation conditions}

six plants were each divided into six parts and one part of each 
plant assigned to each of the six experimental chambers using a random numbers table. In later experiments, a seventh plant was similarly distributed among the chambers after first being killed by keeping it in running tap water above $65^{\circ} \mathrm{C}$ for at least 30 minutes.

The time conditions for each experiment are given in Table 1 . In order to minimize any circadian effects, most experimeńts were started between 12:00 and 14:10 on the same day that the plants were collected. Deviations from this are noted. A preincubation period of about one hour (see Table 1 for exceptions) was started after distributing the plants to the chambers, by turning on the lights, heaters, and gas flow. The incubation period commenced with the addition to each chamber of approximately 50-175 $\mathrm{\mu C}$ Ca-45 (with minimum specific activity of 9 to $32 \mathrm{mCi} \mathrm{mg}^{-1} \mathrm{CaCl}_{2}$ ) and lasted (in the light and the standard experiments) for two hours. In the experiments in which substances other than $\mathrm{CO}_{2}$ were added, it was for one hour (except B3).

\section{Post-incubation procedure}

After incubation the algae were allowed to stand in tap water for several minutes (Table 1). Next the individual plant parts were each placed in a separate petri dish and covered with $6 \%$ sodium hypochlorite (commercial bleach) for three days. Kolesar (1973) found that calcareous algae continued to lose weight for a number of days after being placed in bleach, suggesting that the non-carbonate matrix is not quickly removed. When treated with $0.1 \mathrm{~N} \mathrm{HCl}$ after three days in the bleach, our algae tips showed no evidence of the ghost tissue that was found when non-bleached tips were so treated. 
Radioassay method

Only terminal segments (tips) were assayed, because Pearse (1972) found them to be more active in Ca-45 incorporation than the older branch segments. Six tips were chosen from a plant part, placed on a planchet, and timed for 10,000 counts using a Nuclear-Chicago gas-flow detector. This gave six averages per treatment and six averages per plant for each experiment.

To correct for differences among chambers due to experimental errors, Ca-45 activity of the sea water was measured. One-tenth $\mathrm{ml}$ of sea water was removed from each chamber at the end of each run, added to $5 \mathrm{ml}$ of deionized water and $5 \mathrm{ml}$ of Packard Instagel, and assayed in a liquid scintillation counter. An uncorrected systematic error for the light experiments of about one percent was introduced by assaying the sea water on the day following the experiment rather than at the same time that the tips were counted. In all experiments a background correction factor of $11.5 \mathrm{ct} \mathrm{min}^{-1}$ was subtracted for each sample counted.

\section{Terminal segment size}

To determine the effect of tip size on rate of Ca-45 incorporation, a size sequence of nine tips was incubated for two hours at $0.04 \% \mathrm{P}_{\mathrm{CO}_{2}}$ and $13 \mathrm{~mW} \mathrm{~cm} \mathrm{~cm}^{-2}$ illumination, and then radioassayed. The relative surface areas were computed by tracing microprojector enlargements of the tips onto index cards, cutting the enlargements out, and weighing them.

Although calcification increased as total surface area increased $(r=0.94, p<0.01)$ considerable variability existed (see also Thomas, 1976). Per unit surface area, smaller segments were considerably more 
active than were larger ones. Such a growfh gradient (Fig. 5) for terminal segment development is similar to that found for successively younger branch segments (Pearse, 1972), and occurs also in Halimeda (Borowitzka and Larkum, 1976a), and in the frond of Padina (Ikemori, 1970). 


\section{Calcification and the $\mathrm{CO}_{2}$ concentration}

Over a nine month period ten $\mathrm{P}_{\mathrm{CO}_{2}}$ experiments (Table 5, Fig. 6) were conducted in which six plants were each divided into six parts for simultaneous treatment with six different concentrations of $\mathrm{CO}_{2} \cdot$ Over the $\mathrm{P}_{\mathrm{CO}_{2}}$ range $5.5 \%$ to $0.04 \%$ the resultant $\mathrm{pH}$ ranged from 6.5 to 8.7 depending on the particular $\mathrm{P}_{\mathrm{CO}_{2}}$ and its flow rate. Optimum calcification occurred using $\mathrm{P}_{\mathrm{CO}_{2}}$ levels between 1 and $0.1 \%$ (between $\mathrm{pH}$ of 7 and 8.3 ). Plants incubated at optimal $\mathrm{P}_{\mathrm{CO}_{2}}$ levels 1 three to thirty times that of the present atmospherel calcified about one-third faster than those treated with normal air $\left(P_{\mathrm{CO}_{2}}=0.04 \%\right)$.

Calcification was correlated positively with the calculated concentration of $\mathrm{HCO}_{3}{ }^{-}$expressed as percent of total carbon $1 \mathrm{r}=0.86$, $p<0.01$ ) (Table 6) (see also Riley and Skirrow, 1966, 1975; Whitfield, 1974).

The killed controls calcified at much lower rates than the living plants (Fig. 6).

Increasing $\mathrm{NaHCO}_{3}$ and $\mathrm{Na}_{2} \mathrm{CO}_{3}$ concentrations

Experiment B-1: This experiment (Table 7, Fig. 7) tested the effect upon calcification of increasing the $\mathrm{NaHCO}_{3}$ concentration. Increments of $\mathrm{NaHCO}_{3}$ ( 1 to $\left.16 \mathrm{mM}\right)$ were added and air $\left(\mathrm{P}_{\mathrm{CO}_{2}}=0.23 \%\right.$ ) was bubbled through the chambers. The $\mathrm{pH}$ ranged from 7.8 (no added $\mathrm{NaHCO}_{3}$ ) to $8.1(16 \mathrm{mM}$ added). Calcification increased in living plants almost logarithmically as $\mathrm{NaHCO}_{3}$ increased. Between 1 and $8 \mathrm{mM} \mathrm{NaHCO}$, the killed controls remained at exchange levels. Addition of $16 \mathrm{mM} \mathrm{NaHCO}$. resulted in $\mathrm{Ca}-45$ incorporation in the killed controls similar to that in the living plants. 
Experiment B-2: This experiment was similar to experiment B-1 except that $\mathrm{P}_{\mathrm{CO}_{2}}=0.04 \%$ and the $\mathrm{pH}$ decreased from 8.6 (no added $\mathrm{NaHCO}_{3}$ ) to 8.3 (16 mM NaHCO 3 added). Calcification in living plants increased nearly linearly as a function of increasing $\mathrm{NaHCO}_{3}$ concentration (Fig. 7 ). The killed controls ( 1 to $4 \mathrm{mM}$ added $\mathrm{NaHCO}_{3}$ ) also showed only a slight. increase whereas addition of 8 and $16 \mathrm{mM} \mathrm{NaHCO}_{3}$ to the killed controls caused a marked inerease in Ca-45 uptake that surpassed that of living plants.

Experiment C-1: This experiment differed from the previous two in that $\mathrm{Na}_{2} \mathrm{CO}_{3}$ was used instead of $\mathrm{NaHCO}_{3}$. The addition of $\mathrm{Na}_{2} \mathrm{CO}_{3}$ (1 to 6 $\mathrm{mM})$ increased $\mathrm{pH}$ levels beyond those obtained by bubbling air $\left(\mathrm{P}_{\mathrm{CO}_{2}}=\right.$ $0.04 \%$ ) alone through the sea water. The resultant pH ranged from 8.5 (no added $\mathrm{Na}_{2} \mathrm{CO}_{3}$ ) to $9.4(6 \mathrm{mM}$ added). In the living plants, calcification showed a nearly direct linear correlation with the $\mathrm{Na}_{2} \mathrm{CO}_{3}$ concentration. The killed controls increased more rapidly at the higher concentrations (Fig. 7).

\section{Buffers}

Experiments $\mathrm{H}-1$ and $\mathrm{H}-2$ : My. attempts to separate the effect of $\mathrm{pH}$ from that of the different carbon species by using buffers are sumarized in Table 8. Experiment $H-1$ simultaneously tested the effects on six different plants of five different $\mathrm{P}_{\mathrm{CO}_{2}}$ levels Iranging from 0.04 to $1 \%$ $\mathrm{P}_{\mathrm{CO}_{2}}$ ' on calcification in the presence of $20 \mathrm{mM}$ HEPES buffer. Two-way analysis of variance (Table 9) showed that a difference existed both between $\mathrm{P}_{\mathrm{CO}_{2}}$ levels and between plants. Each one of the six plants calcified at a higher rate at $\mathrm{P}_{\mathrm{CO}_{2}}=1 \%$ than at any of the other levels. 
Experiment $\mathrm{H}-2$ simultaneously compared TRIS, HEPES, and $\mathrm{NaHCO}_{3}$ buffers at the $\mathrm{P}_{\mathrm{CO}_{2}}$ levels of 0.04 and $0.26 \%$. Two-way analysis of variance (Table 9 ) showed that a difference in calcification existed at $\mathrm{P}_{\mathrm{CO}_{2}}=0.04 \%$ between TRIS, HEPES and sea water to which no extra $\mathrm{NaHCO}_{3}$ was added but that the plants weren't different. The same test (Table 9) but with $\mathrm{P}_{\mathrm{CO}_{2}}=0.26 \%$, TRIS, HEPES, and sea water buffered with added $\mathrm{NaHCO}_{3}$ again showed the treatments to differ.

The living plants in Experiment $\mathrm{H}-2$ treated with TRIS and HEPES did not incorporate Ca-45 faster than the dead controls. Living controls in plain sea water and a $\mathrm{P}_{\mathrm{CO}_{2}}$ of $0.04 \%$ incorporated $\mathrm{Ca}-45$ about twice as fast as the dead controls. However, this was less than half the uptake obtained for both living plants and killed controls with a $\mathrm{P}_{\mathrm{CO}_{2}}$ of $0.26 \%$ and the addition of successive $\mathrm{NaHCO}_{3}$ increments (Table 8) to keep the $\mathrm{pH}$ around 8.2 . 
My research has shown that increasing the partial pressure of carbon dioxide in sea water increases calcification in the coralline alga Bossiella orbigniana (Fig. 6). This increase is correlated directly with the $\mathrm{HCO}_{3}$ - concentration expressed as percent of total carbon. Maximum calcification occurred at concentrations several times those of current atmospheric levels; and concentrations of $\mathrm{CO}_{2}$ greater than 50 times that of current atmospheric levels were required before calcification fell below that obtained using present atmospheric concentrations. In my experiments $\mathrm{pH}$ dropped more than the $\frac{1}{2}$ unit given by Plass (1956): It should be noted that when maximum calcification occurred, $\left[\mathrm{CO}_{2}\right] \approx\left[\mathrm{CO}_{3}^{2-}\right]$ and $\left[\mathrm{HCO}_{3}^{-}\right]$was at its maximum (as percent of total carbon). Decrease in calcification from optimum levels closely coincided with increasing $\mathrm{CO}_{2}$

During the two hour incubation period, the $\mathrm{pH}$ consistently rose 0.1 to 0.3 units in the chambers into which air $\left(\mathrm{P}_{\mathrm{CO}_{2}}=0.04 \%\right)$ was being bubbled. This did not occur at other $\mathrm{CO}_{2}$ levels. Possible explanations are that the plants (1) utilized $\mathrm{CO}_{2}$ faster than it was being delivered, (2) removed $\mathrm{HCO}_{3}^{-}$or $\mathrm{CO}_{3}^{2-}$ faster than the hydration of $\mathrm{CO}_{2}$ permitted their formation (skirrow, 1975), and (3) released a product such as $\mathrm{OH}^{-}$ faster than compensation by $\mathrm{CO}_{2}$ could occur. This rise in $\mathrm{pH}$ suggests that not only would a higher atmospheric concentration of $\mathrm{CO}_{2}$ be needed to enhance growth rates, but also adequate mixing as well. This is supported by Smith and Kinsey (1976), who report that seaward portions of coral reefs where adequate mixing would be expected produce five times as much calcium carbonate as do the protected areas. They suggest that 
the difference is probably largely a function of water motion.

The near linearity at high $\mathrm{pH}$ values of Ca-45 uptake by the living plants, even at concentrations that caused marked precipitation in the killed controls (Fig. 7) strongly suggests that living plants are able to control calcification rates. This is in agreement with the work of a number of investigators, as summarized by Clark (1976), who suggest that marine organisms are able to regulate calcification, even under conditions where the solubility product of $\mathrm{CaCO}_{3}$ is exceeded.

According to Chalker (1976) the suggested logarithmic uptake (my Fig. 7) at $\mathrm{P}_{\mathrm{CO}_{2}}=0.26 \%$ and increasing $\mathrm{NaHCO}_{3}$ concentration can be explained with Michaelis - Menten kinetics. The nearly linear uptake at $\mathrm{P}_{\mathrm{CO}_{2}}=0.04 \%$ and increasing $\mathrm{NaHCO}_{3}$ or $\mathrm{Na}_{2} \mathrm{CO}_{3}$ concentrations suggests that simple diffusion may be rate-limiting at higher pH levels.

since calcification in coralline algae is poorly understood, comparison with other calcifying organisms may be helpful. In coccolithophorids and in corals, membrane transport must be considered because $\mathrm{Ca}^{++}$and carbon species must cross a membrane to reach the calcification site. However, in Halimeda and Bossiella the $\mathrm{Ca}^{++}$or carbon species would not have to pass through a membrane and the cells adjacent to the calcification sites may modify the environment where calcification takes place Isee Borowitzka and Larkum, 1976a). Such differences suggest that generalizations comparing calcifying organisms should be proposed with caution.

Somewhat similar results to my $\mathrm{P}_{\mathrm{CO}_{2}}$ experiments $(\mathrm{S}-1$ to $\mathrm{S}-10)$ were reported by Paasche (1964) for the unicellular marine alga coccolithus huxleyi. This organism calcified most rapidly under his conditions at levels similar to each other at $\mathrm{pH}=7.5,8.0$, and 8.5 . The relative 
calcification level dropped about $50 \%$ at $\mathrm{pH}=9.1$ and $100 \%$ at $\mathrm{pH}=6.3$. He used TRIS buffer, which inhibited calcification in my organisms (Table 8 ) and may have been responsible for the similarity in his calcification rates from $\mathrm{pH}=7.5$ to 8.5 in Coccolithus huxleyi; this is the optimum working range for TRIS (Smith and Hood, 1964). Changing the $\mathrm{P}_{\mathrm{CO}_{2}}$ changes the $\mathrm{pH}$ and the concentrations of the various carbon species in sea water (Fig. 4). This close relationship between $\mathrm{pH}$ and $\mathrm{P}_{\mathrm{CO}_{2}}$ makes it difficult to establish cause and effect relationships when dealing with the $\mathrm{CO}_{2}$ system. Lucas (1974) claims that both $\mathrm{CO}_{2}$ and $\mathrm{HCO}_{3}^{-}$are utilized by chara, a carbonate precipitating fresh water green alga. Jolliffe and Tregunna (1970) present evidence that $\mathrm{HCO}_{3}{ }^{-}$and not $\mathrm{CO}_{2}$ is utilized by several different marine algae. The rate of coccolith formation in coccolithus huxleyi reaches a maximum level at about $20 \mathrm{mM}$ total carbon concentration according to paasche (1964). Natural sea water contains only about $2 \mathrm{mM}$ total carbon. Paasche (1964) and Crenshaw (1964) both claim that at least some coccol ithophorids utilize $\mathrm{HCO}_{3}^{-}$. However, Steemann Nielsen (1975) states that no experiments showing $\mathrm{HCO}_{3}^{-}$utillization by marine plants can be shown except for coccolithus huxleyi, which he considers a special case.

My results suggest that calcification in Bossiella orbigniana may utilize $\mathrm{HCO}_{3}^{-}$and that $\mathrm{CO}_{2}$ and $\mathrm{CO}_{3}^{2-}$ may compete with it (Table 6 and .Fig. 4l. The occurrence of maximum calcification at maximum $\mathrm{HCO}_{3}{ }^{-}$, expressed as percent of the total carbon concentration, and the decrease in calcification as either $\mathrm{CO}_{2}$ or $\mathrm{CO}_{3}^{2-}$ increases (thus making $\mathrm{HCO}_{3}^{-}$a smaller percent of the total carbon), seems more than coincidental. 
However, a suitable experiment remains to be devised to convincingly demonstrate this. The possibility remains that we may be dealing with a $\mathrm{pH}$ sensitive system whose optimum coincides with bicarbonate values $($ Fig. 4).

My experiments in which $\mathrm{NaHCO}_{3}$ and $\mathrm{Na}_{2} \mathrm{CO}_{3}$ concentrations were increased (Fig. .7) help to sort out the effect of inorganic precipitation (as seen in the killed controls). Calcification in the killed controls appears to be a function of the increasing $\mathrm{Na}_{2} \mathrm{CO}_{3}$ concentration (compare Fig. 4l at least at low concentrations of added carbon. At the higher added concentrations ( 8 or $16 \mathrm{mM} \mathrm{NaHCO}_{3}$ and $2 \mathrm{mM}$ or more $\mathrm{Na}_{2} \mathrm{CO}_{3}$ ) apparently the solubility product of $\mathrm{CaCO}_{3}$ is greatly exceeded, resulting in precipitation onto the killed but not the living plants.

The effects of $\mathrm{pH}$ on calcification in the green alga Halimeda were studied by Borowitzka and Larkum (1976b) using a closed system and varying $\mathrm{pH}$ with $\mathrm{NaHCO}_{3}$ and various organic buffers. Although they report calcification as being "fairly constant in the $\mathrm{pH}$ range 6.5 to 8.2 " (based on three points) the highest point of calcification in this range is at a pH similar to my optimum. Possibly if more points or replicates could be used, calcification in Halimeda would be shown to vary with $\mathrm{pH}$ in a manner similar to that of Bossiella.

Using Cricosphaera elongata, a different coccolithophorid than that used by Paasche (1964), Swift and Taylor (1966) measured the division rate as a function of $\mathrm{pH}$. They varied $\mathrm{pH}$ by using a combination of two different $\mathrm{P}_{\mathrm{CO}_{2}}$ 's $10.03 \%$ and $5 \%$ ) and adding 0.1 to $60 \mathrm{mM} \mathrm{NaHCO}{ }_{3}$. They did not use other buffers. Their pH curve is similar to mine IFig. 61 , with both showing maximum calcification at about $\mathrm{pH}=7.8$. They 
claim that $\mathrm{pH}$ and not the concentration of the carbon species is responsible for their results. It should be noted that their system was not in equilibrium with the atmosphere (see my Fig. 4 ).

If the above objections can be met, the similarity of my pH optimum results to those of Swift and Taylor (1966), Paasche (1964), and Borowitzka and Larkum (1976b), suggest that a common biological process may control both the rate of division and calcification in coccolithophorids and that of calcification in Bossiella, and possibly Halimeda. 
CONCLUSIONS

1. Calcification was correlated with size of terminal segment, with the smallest (youngest) tips incorporating the most Ca-45 per unit surface area.

2. Maximum calcification of about one-third above normal occurred when bicarbonate concentration, as percent of total carbon, was at its maximum. This occurred when $\mathrm{P}_{\mathrm{CO}_{2}}$ was between $1 \%$ and $0.1 \%$, probably between $0.4 \%$ and $0.1 \%$. For my synthetic sea water, the resultant pH range was 7.6 to 8.3 .

3. Addition of either $\mathrm{NaHCO}_{3}$ or $\mathrm{Na}_{2} \mathrm{CO}_{3}$ markedly increased calcification. At high pH, calcification increased in living plants as a nearly linear function of concentration; it increased more rapidly in killed controls. This suggests that the diffusion rate may have been the limiting factor and that simple precipitation was not occurring in the living plants, at least not at the rate it appeared to be increasing in the killed controls.

4. Both HEPES and TRIS buffers at 20-25 mM concentration reduced calcification to the level of the killed controls. Only when the experiment using HEPES had continued long enough for the buffer to become saturated (as seen by changing $\mathrm{pH}$ ) did calcification begin to occur.

5. $\mathrm{NaHCO}_{3}$ functioned well as a buffer and increased calcification, but was not useful for separating the effects of the concentrations of the various carbon species from those of $\mathrm{pH}$ since it is itself a carbon species. 
6. Calcification is dependent on a number of factors related to the pH$\mathrm{P}_{\mathrm{CO}_{2}}$ system. At high pH (low $\mathrm{P}_{\mathrm{CO}_{2}}$ ) increasing $\left[\mathrm{CO}_{3}^{2-}\right.$ ] may diffuse through the cell wall and precipitate onto available calcification lattice sites. In the $\mathrm{pH}$ range 6.5 to 8.7 the calcification rate was correlated directly with the $\left[\mathrm{HCO}_{3}^{-}\right]$expressed as percent of total carbon. This suggests that $\mathrm{pH}$ and/or $\mathrm{HCO}_{3}^{-}$may be rate limiting. Both $\mathrm{CO}_{2}$ and $\mathrm{CO}_{3}^{2-}$ may compete with the process when the system is in equilibrium. The possibility that molecular $\mathrm{CO}_{2}$ may be responsible for the increase in calcification up to $0.26 \%$ or more $\mathrm{P}_{\mathrm{CO}_{2}}$ has not been ruled out, but this does not seem to be the simplest explanation. 
TABLE 1. EXPERIMENTAL PARAMETERS (in hours and minutes)

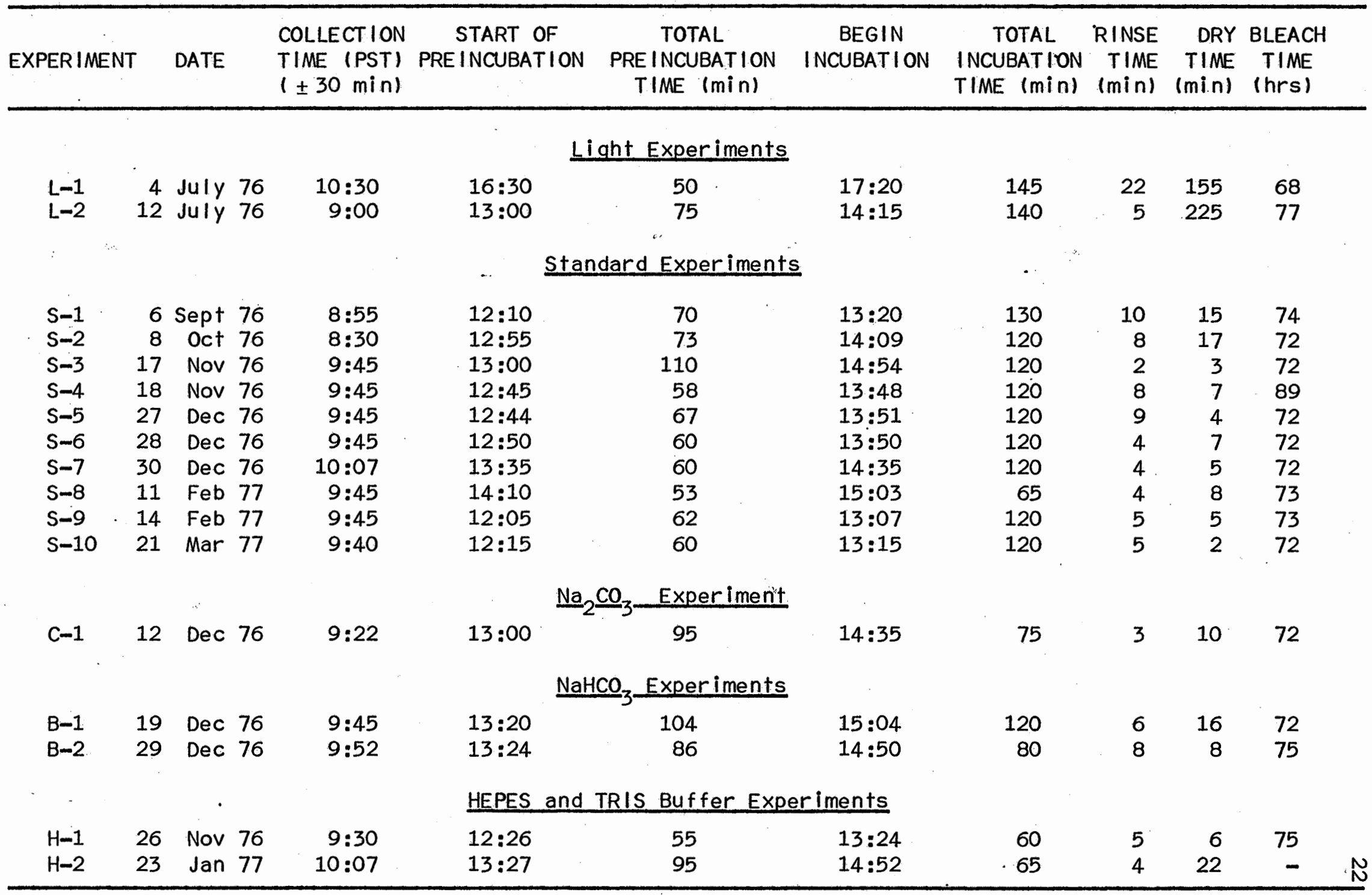


TABLE 2. BEGINNING AND ENDING PH VALUES FOR EXPERIMENTS $s-1$ TO $s-10$

\begin{tabular}{|c|c|c|c|c|c|c|c|c|c|c|}
\hline$P_{\mathrm{CO}}$ & $(\%)$ & 5.46 & 2.26 & 1.05 & 0.93 & 0.39 & 0.26 & 0.23 & 0.11 & 0.04 \\
\hline \multirow[t]{10}{*}{ Exp } & $s-1$ & - & $6.92-6.97$ & - & $7.25-7.24$ & $7.83-7.68$ & - & $8.01-7.88$ & $8.42-8.49$ & $8.59-8.81$ \\
\hline & $s-2$ & - & -7.06 & - & -7.34 & -7.67 & - & -7.96 & -8.39 & -8.99 \\
\hline & $s-3$ & - & $6.86-6.85$ & - & $7.13-7.10$ & $7.65-7.55$ & - & $7.89-7.78$ & $8.33-8.31$ & $8.67-8.78$ \\
\hline & $s-4$ & - & -6.85 & - & -7.14 & -7.60 & - & -7.85 & -8.17 & -8.83 \\
\hline & $s-5$ & - & $6.77-6.76$ & $7.10-7.04$ & - & $7.54-7.47$ & - & $7.82-7.74$ & $8.24-8.19$ & $8.52-8.61$ \\
\hline & $s-6$ & - & $6.80-6.73$ & $7.10-7.01$ & - & $7.53-7.46$ & - & $7.84-7.74$ & $8.30-8.23$ & $8.53-8.67$ \\
\hline & $s-7$ & $6.29-6.36$ & $6.69-6.69$ & $7.01-6.99$ & - & $7.46-7.45$ & - & $7.74-7.74$ & - & $8.42-8.73$ \\
\hline & $s-8$ & $6.47-6.50$ & $6.82-6.80$ & $7.13-7.11$ & - & - & $7.83-7.81$ & - & $8.51-8.41$ & $8.59-8.71$ \\
\hline & $s-9$ & $6.58-6.58$ & $6.88-6.88$ & $7.14-7.14$ & - & - & $7.80-7.80$ & - & $8.42-8.41$ & $8.64-8.82$ \\
\hline & $s-10$ & $6.62-6.65$ & $6.87-6.89$ & $7.15-7.14$ & - & - & $7.82-7.78$ & - & $8.22-8.19$ & $8.62-8.69$ \\
\hline & $n$ & . 4 & 10 & 6 & 4 & 7 & 3 & 7 & 9 & 10 \\
\hline \multicolumn{2}{|c|}{$\bar{x} \pm$ S.E. } & $6.51 \pm 0.07$ & $6.83 \pm 0.03$ & $7.09 \pm 0.02$ & $7.21 \pm 0.05$ & $7.59 \pm 0.04$ & $7.81 \pm 0.01$ & $7.84 \pm 0.09$ & $8.32 \pm 0.04$ & $8.70 \pm 0.04$ \\
\hline \multicolumn{2}{|c|}{ Combined for } & Fig. 6 & $\rightarrow$ & \multicolumn{2}{|c|}{$7.14 \pm 0.03$} & \multicolumn{3}{|c|}{$7.83 \pm 0.04$} & & \\
\hline
\end{tabular}


TABLE 3. PARAMETERS USED FOR CALCULATION OF CARBON SPECIES CONCENTRATIONS FOR $19^{\circ} \mathrm{C}$ AND $19 \% \mathrm{Cl}$ SEA WATER ${ }^{1}$

Solubility of $\mathrm{CO}_{2}$ in sea water $\left(\alpha_{s}\right)$

$340 \times 10^{-4}$ moles $^{-1} \mathrm{~atm}^{-1}$

$K_{i 1}=$ first apparent dissociation constant of carbonic acid

$9.419 \times 10^{-7}$ moles $^{-1}$

$\mathrm{pK}_{11}^{\prime}=-\log \left[\mathrm{K}_{11}^{\prime}\right]$

6.026

$\mathrm{K}_{21}^{\prime}=$ second apparent dissociation constant of carbonic acid

$6.577 \times 10^{-10}$ moles $1^{-1}$

$\mathrm{PK}_{21}^{1}=-\log \left[\mathrm{K}_{21}^{\prime}\right]$

9.182

Partial pressure of carbon dioxide $0.04 \%$ to $5.46 \%=400$ to $54,600 \mathrm{ppm}=.0004 \mathrm{~atm}$ to 546 atm

$\left[\mathrm{H}_{2} \mathrm{CO}_{3}\right]=\mathrm{P}_{\mathrm{CO}_{2}} \cdot \alpha_{s}$ where $\mathrm{H}_{2} \mathrm{CO}_{3}$ includes molecular $\mathrm{CO}_{2}$ concentration

$\left[\mathrm{HCO}_{3}{ }^{-}\right]=\mathrm{P}_{\mathrm{CO}_{2}} \cdot \alpha_{\mathrm{s}} \cdot \mathrm{K}_{1_{1}}^{\prime} /\left[\mathrm{a}_{\mathrm{H}}{ }^{+}\right]$

$\left[\mathrm{CO}_{3}^{2-}\right]=\mathrm{P}_{\mathrm{CO}_{2}} \cdot \alpha_{\mathrm{s}} \cdot \mathrm{K}_{11}^{\prime} \cdot \mathrm{K}_{21}^{\prime} /\left[\mathrm{a}_{\mathrm{H}}+\right]^{2}$

Total carbon $=\left[\mathrm{H}_{2} \mathrm{CO}_{3}\right]+\left[\mathrm{HCO}_{3}^{-}\right]+\left[\mathrm{CO}_{3}^{2-}\right]$

${ }^{1}$ From Skirrow (1975) and Park (1969). 
TABLE 4. LIGHT INTENSITY AND CALCIFICATION ${ }^{1}$

\begin{tabular}{|c|c|c|c|c|c|c|c|c|c|c|}
\hline Light intensity $\left(\mathrm{mW} \mathrm{cm} \mathrm{cm}^{-2}\right.$ ) & 0 & 0.1 & 0.4 & 0.8 & 1.0 & 1.2 & 1.3 & 2.3 & 5.0 & 10 \\
\hline Experiment $L-1^{2}$ & $62 \pm 4$ & $77 \pm 4$ & $82 \pm 5$ & & & & $75 \pm 6$ & $83 \pm 5$ & $89 \pm 5$ & \\
\hline Experiment $L-2$ & $84 \pm 7$ & & & $93 \pm 11$ & $86 \pm 7$ & $90 \pm 8$ & & & $91 \pm 7$ & $73 \pm 8$ \\
\hline
\end{tabular}

${ }^{1}$ Each entry is the mean \pm 1 S.E. of 6 plants, given in ct $\mathrm{min}^{-1} \mathrm{tip}^{-1} \mathrm{hr}^{-1}$. See Table 9 for ANOVA.

2 Experiment $L-1$ was held overnight in the dark $(30 \mathrm{hrs})$ before use, whereas Experiment $L-2$ was run on the same day that the plants were collected.

$\rightarrow$ All experiments except $L-1$ and $L-2$ were run at this light intensity. 
TABLE 5. CALCIFICATION IN EXPERIMENTS $S-1$ TO $S-10$

PARTIAL PRESSURE OF $\mathrm{CO}_{2}(\%$ in air)

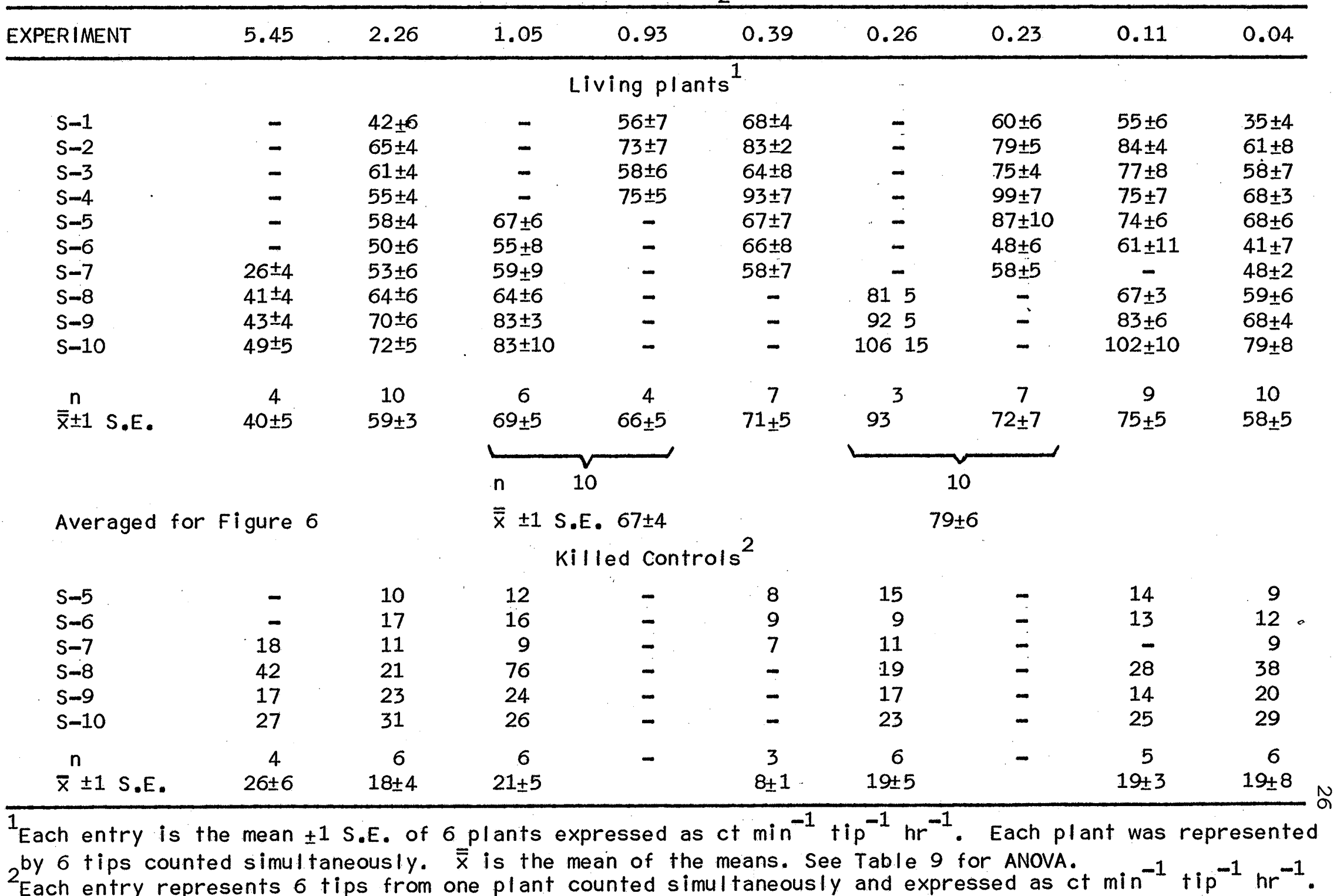


TABLE 6. CORRELATION COEFFICIENTS COMPARING CALCIFICATION WITH $\mathrm{HCO}_{3}{ }^{-}$EXPRESSED AS PERCENT OF TOTAL CARBON

\begin{tabular}{llllllllllll}
\hline PARTIAL PRESSURE $\mathrm{CO}_{2}(\%)$ & 5.45 & 2.26 & 1.05 & 0.93 & 0.39 & 0.26 & 0.23 & 0.11 & 0.04 & $\mathrm{P}$ & \\
\hline $\mathrm{HCO}_{3}^{-}(\% \text { of total carbon })^{1}$ & 70 & 83 & 91 & 91 & 45 & 95 & 95 & 94 & 88 & $0.87<0.01$ \\
Calcification & 40 & 59 & 69 & 66 & 71 & 93 & 72 & 75 & 58 & \\
\hline
\end{tabular}

${ }_{2}^{1}$ From Figure 4.

${ }^{2}$ From Table 5 and Figure $6\left(c+\min ^{-1}+i p^{-1} h^{-1}\right)$. 
TABLE 7. $\mathrm{NaHCO}_{3}$ AND $\mathrm{Na}_{2} \mathrm{CO}_{3}$ EXPERIMENTS

EXPERIMENT B-1 $\mathrm{NaHCO}_{3}$ ADDED. $\mathrm{P}_{\mathrm{CO}_{2}}=0.23 \%$

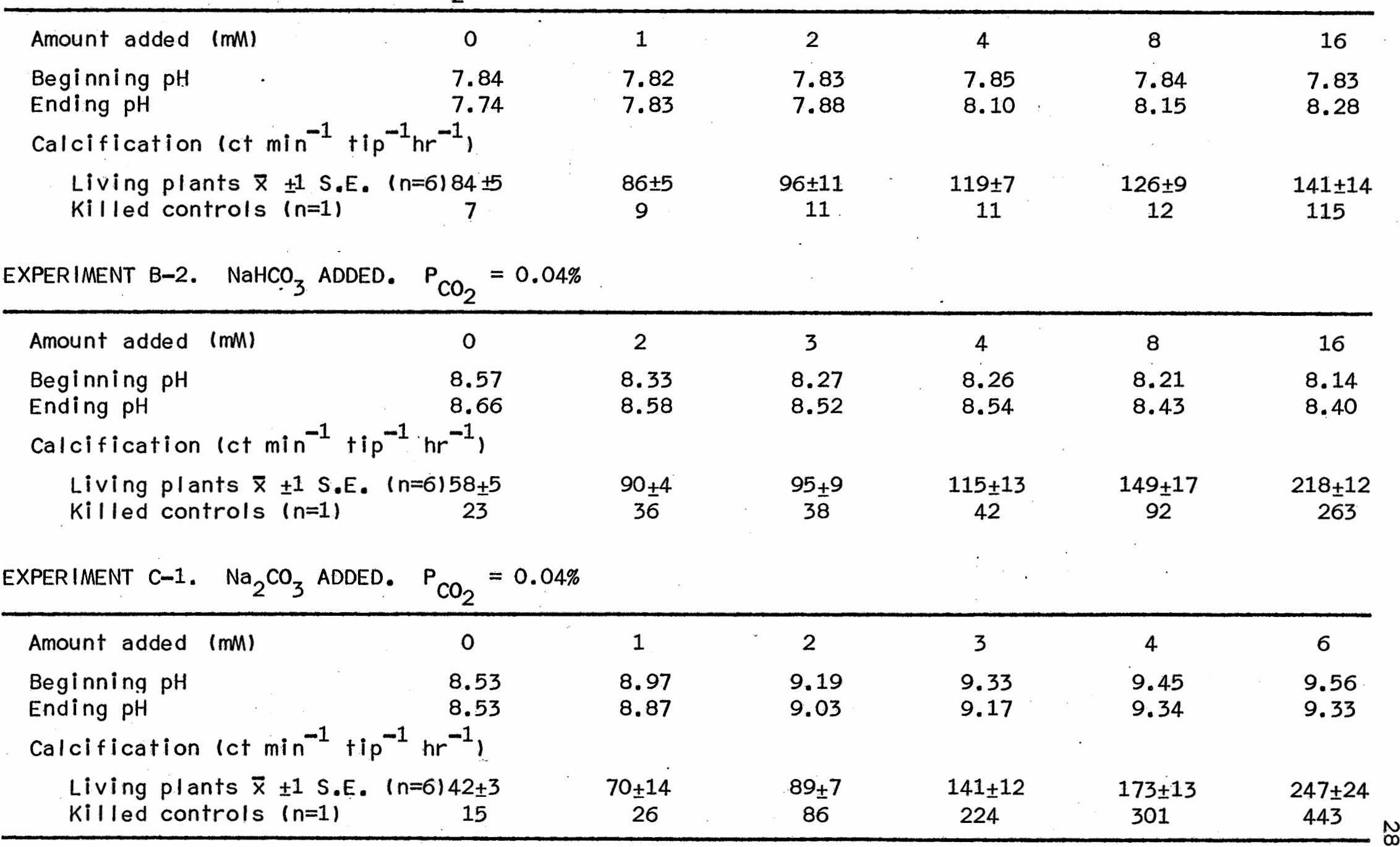


TABLE 8. EFFECT OF BUFFERS ON CALCIFICATION

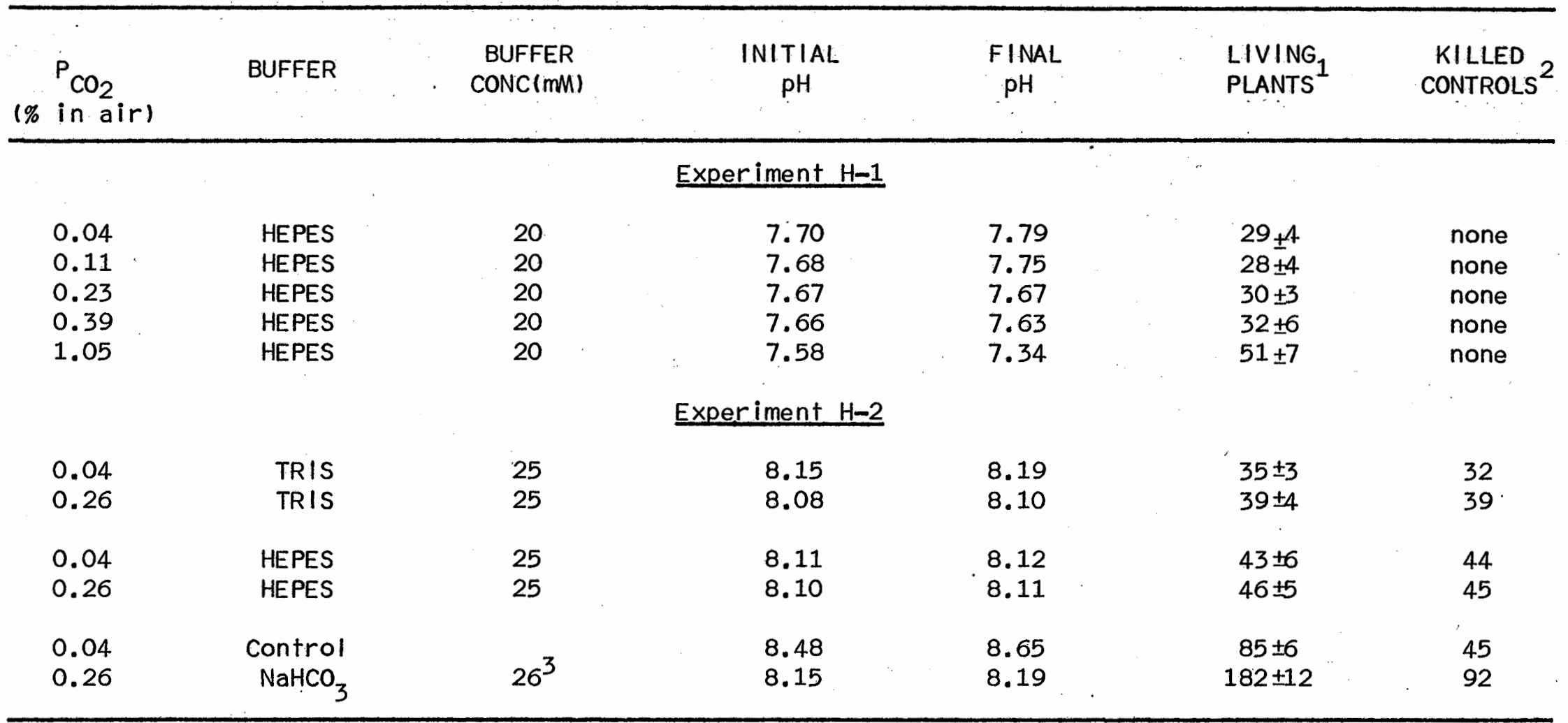

${ }_{2}^{1}$ Average of 6 plants \pm 1 S.E. expressed as ct $\min ^{-1} \operatorname{tip}^{-1} h r^{-1}$. See Table 9 for ANOVA. 2 One plant expressed as ct $\mathrm{min}^{-1} \operatorname{tip}^{-1} \mathrm{hr}^{-1}$.

Added in successive millimolar increments of $8,2,4,4,4$, and 4 to keep pH stable. 
TABLE 9. ANALYSES OF VARIANCE OF DATA (Via General Linear Hypothesis or Two-way ANOVA)

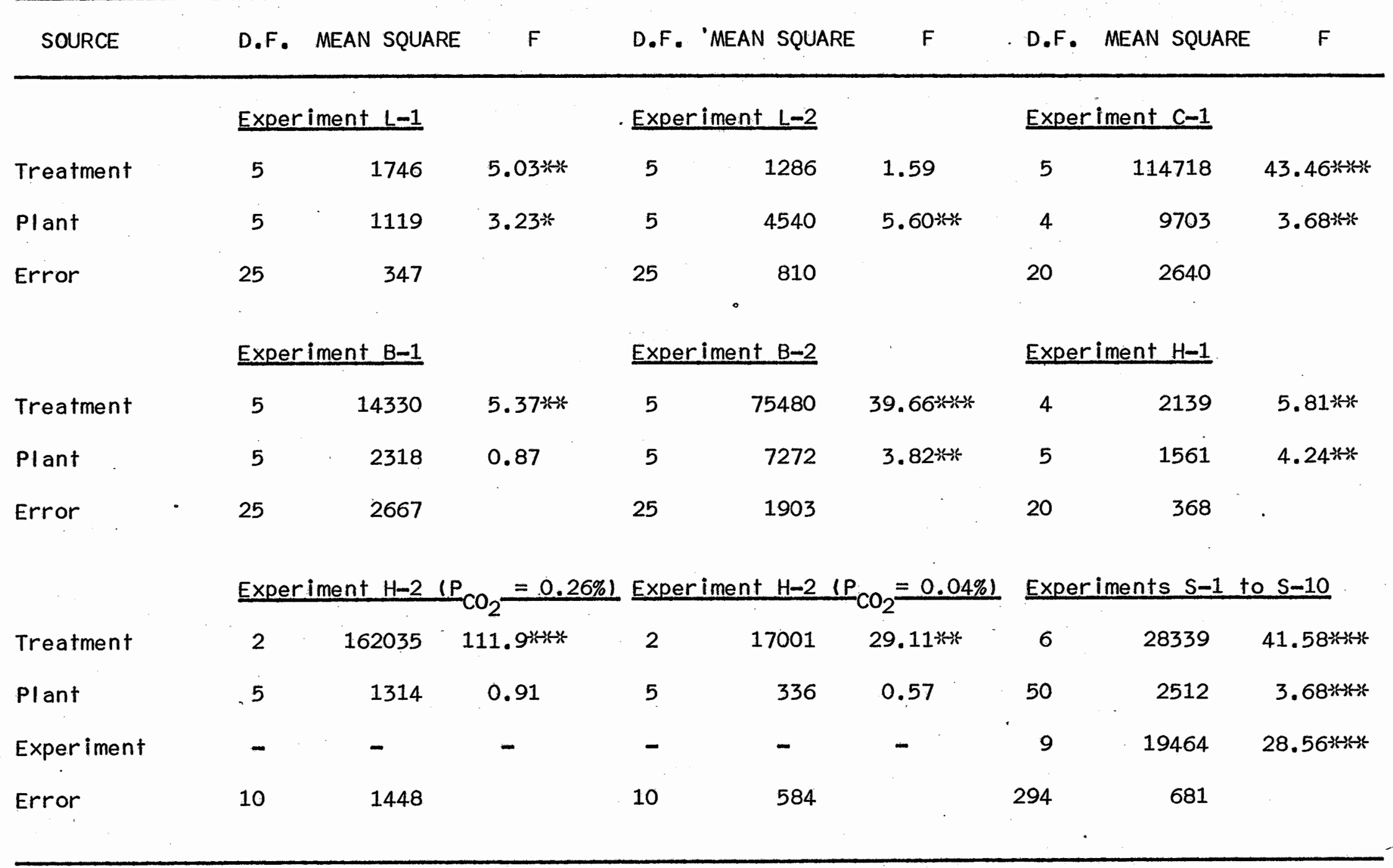


Figure 1. Plexiglass chamber with plants in sea water. 


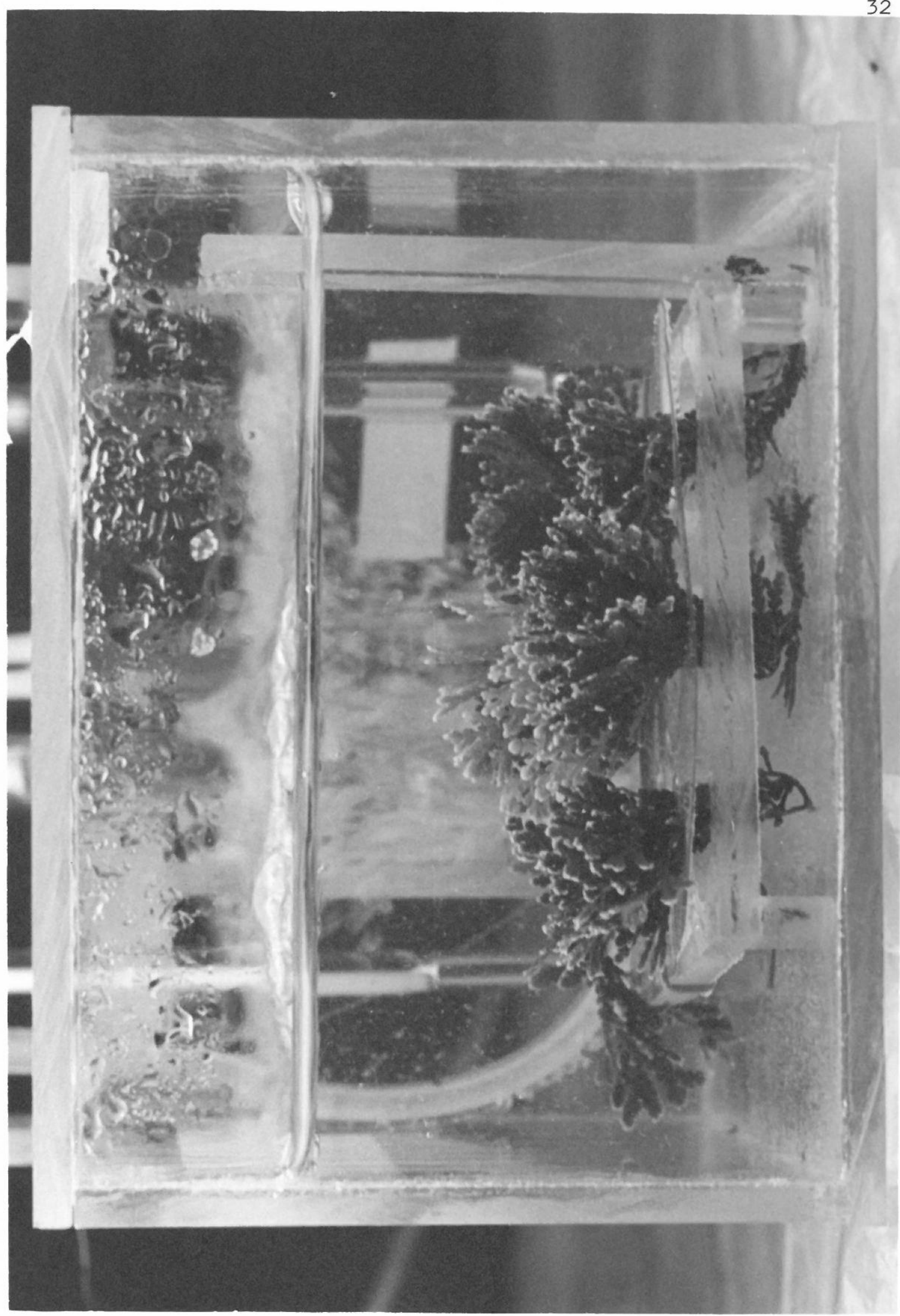


Figure 2. General view of experimental apparatus. 


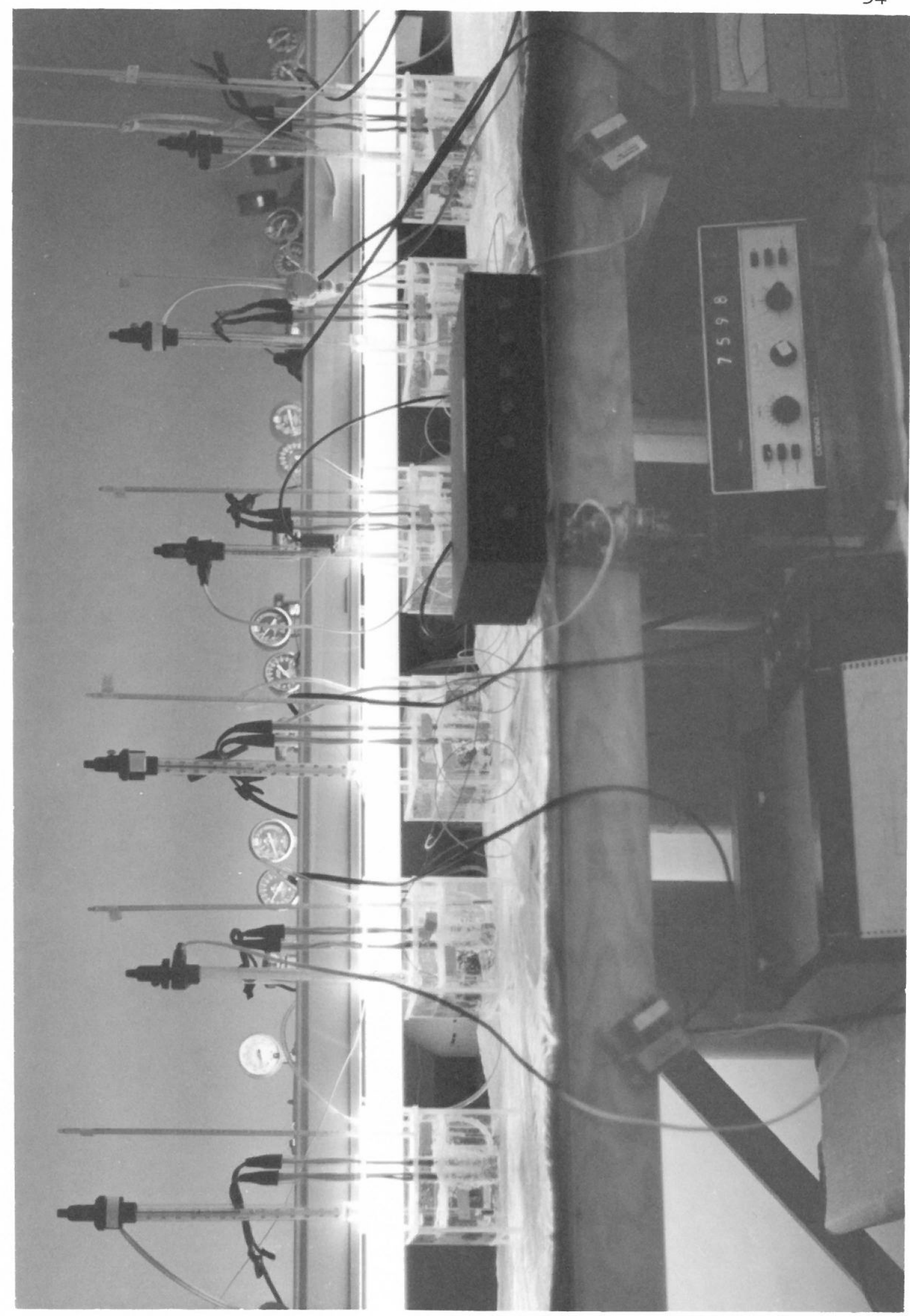


Figure 3. Relation between partial pressure of carbon dioxide in air $\left(\mathrm{P}_{\mathrm{CO}_{2}}\right)$ and $\mathrm{pH}$. The equation for the least squares line is $\mathrm{pH}=1.065\left(-\log \mathrm{P}_{\mathrm{CO}_{2}}\right)^{\prime}+5.07$. The points are based on the sea water $\mathrm{pH}$ readings obtained in Experiments $\mathrm{s}-1$ to $\mathrm{s}-10$ and the measured $\mathrm{P}_{\mathrm{CO}_{2}}$ values of the air in the tanks. 


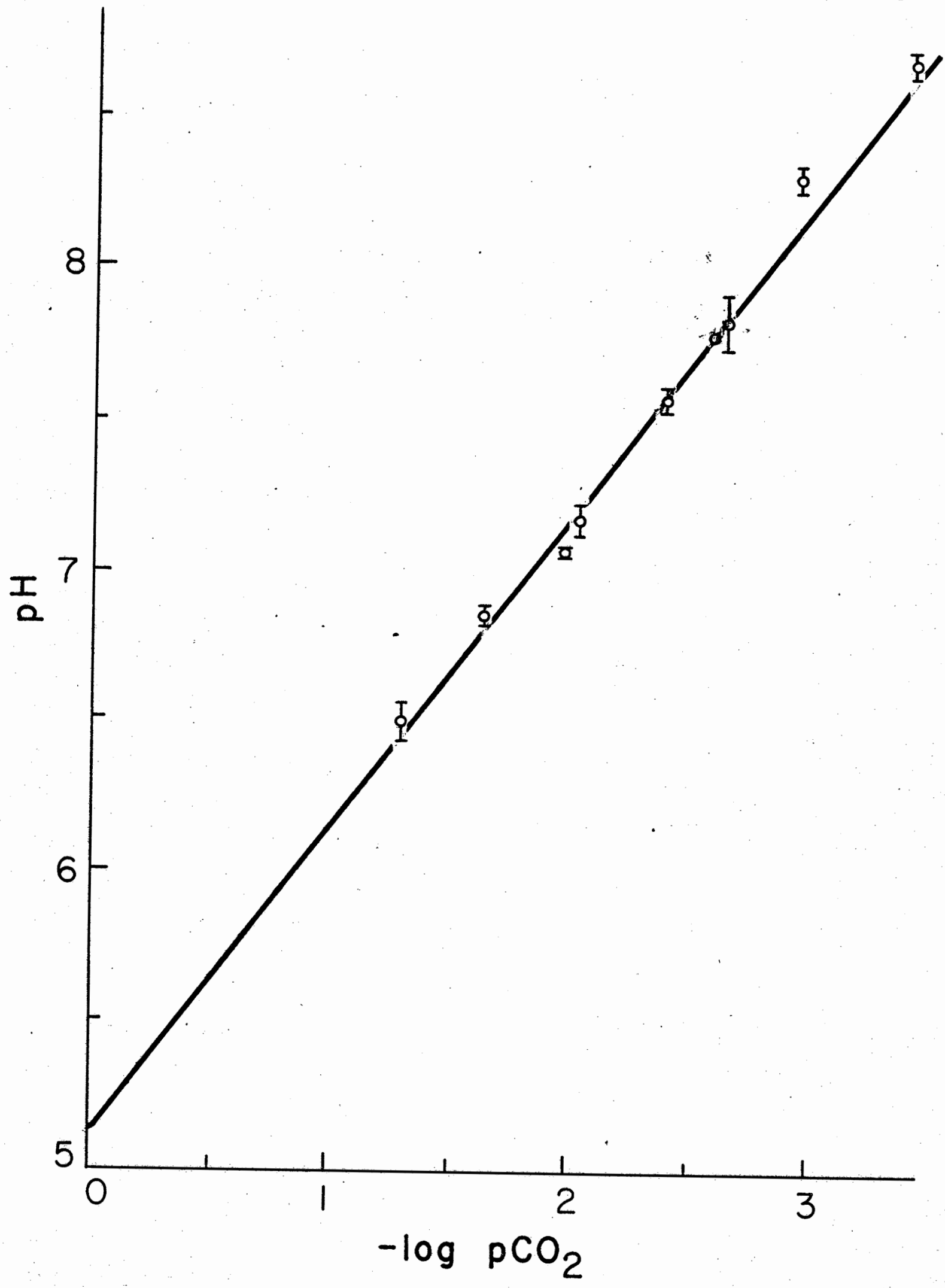


Figure 4. Concentrations of carbon species, expressed as percent of total carbon, in synthetic sea water, calculated from the tank $\mathrm{P}_{\mathrm{CO}_{2}}$ values and the resultant sea water $\mathrm{pH}$ values. See Table 3 for parameters. 


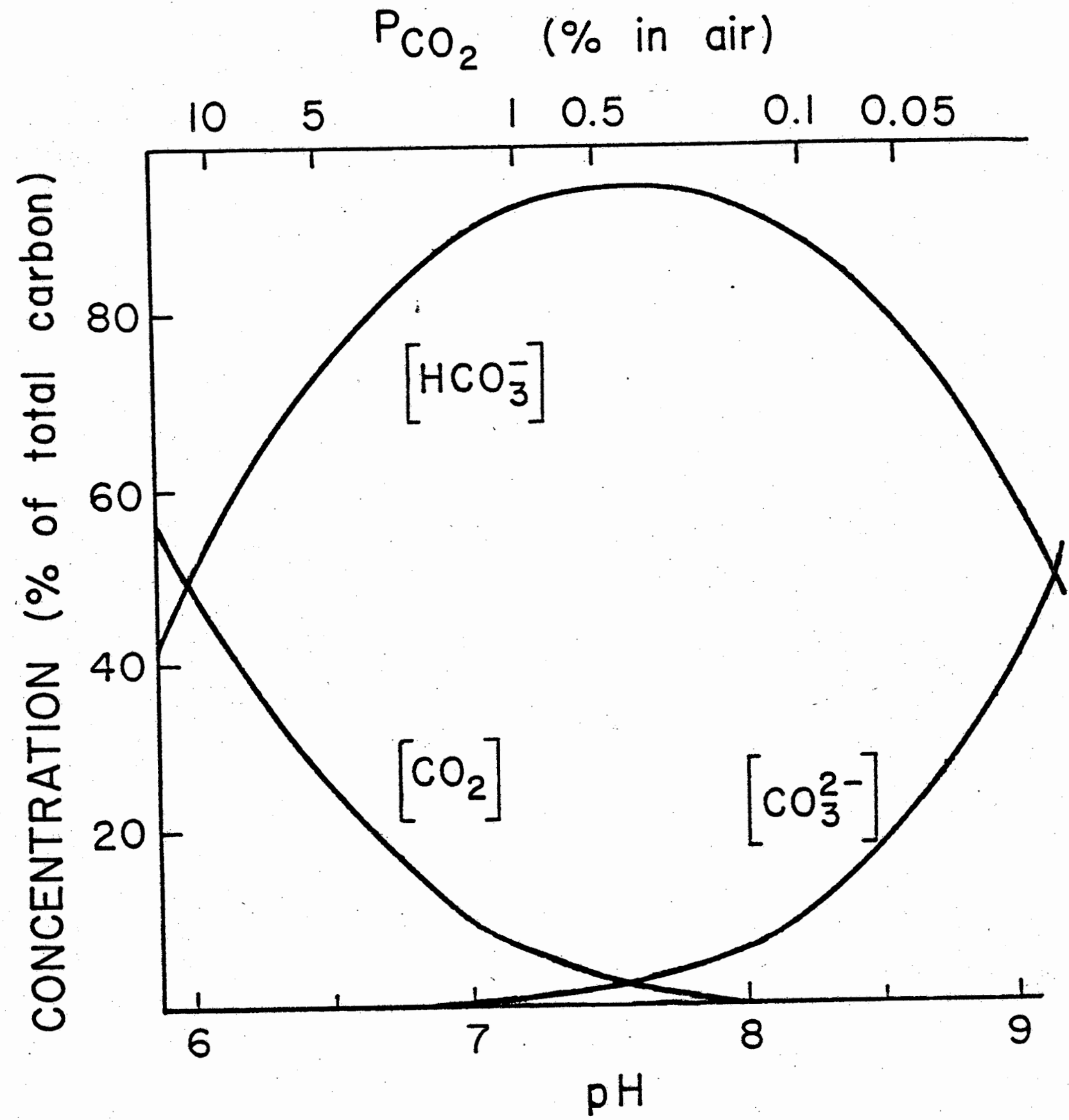


Figure 5. Calcification as a function of area of terminal segment. Each point represents one segment. The units of total surface area are relative only and refer to the weights of the paper used to estimate area. 


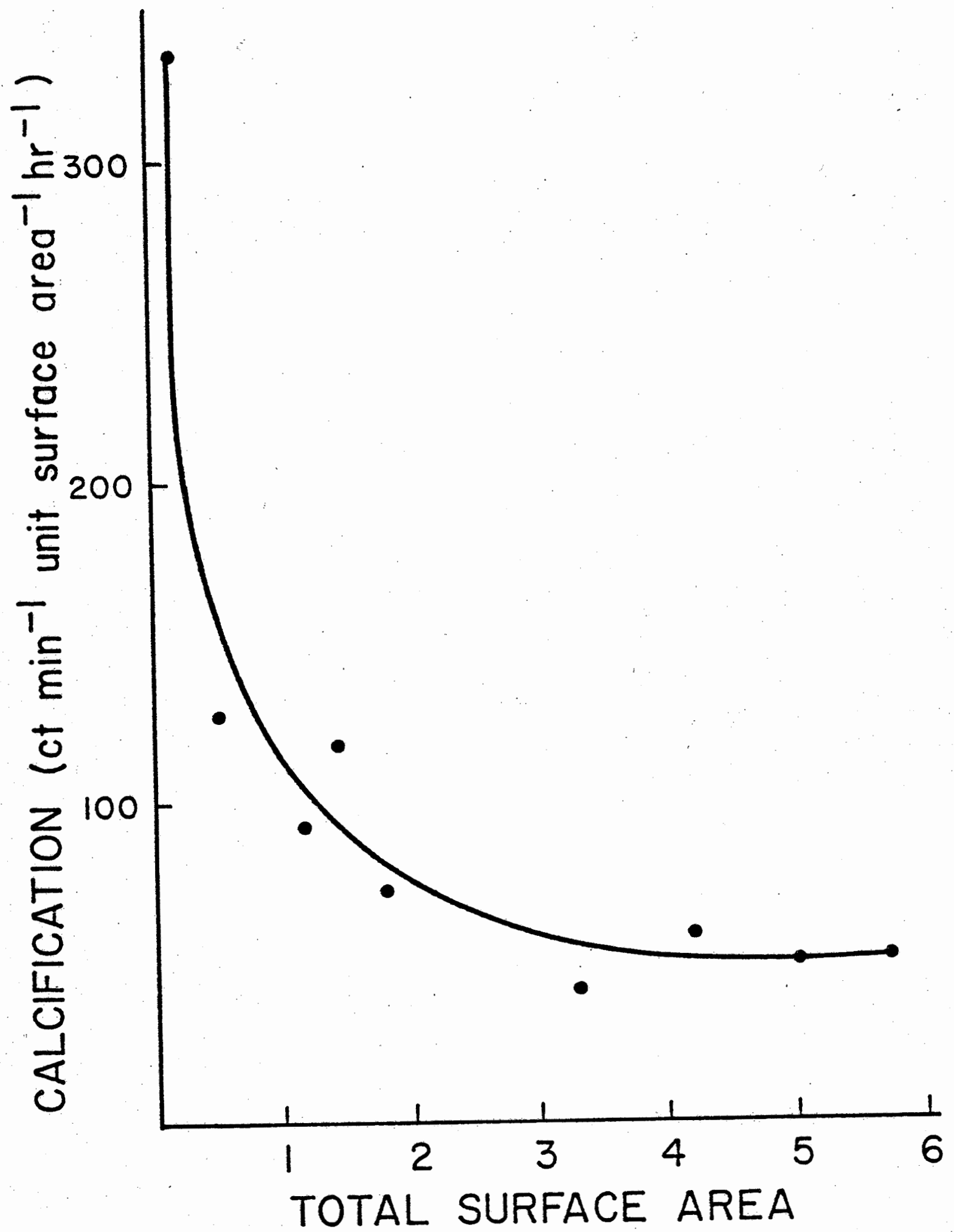


Figure 6. Calcification of Bossiella orbigniana expressed as a function of measured $\mathrm{pH}$ (lower scale) and of calculated $\mathrm{P}_{\mathrm{CO}_{2}}$ (top scale). Note that the top scale is logarithmic and is derived from the least squares line of Figure 3. Each open circle represents the mean \pm 1 S.E. of $(n)$ experiments of 6 living plants each. Each closed circle represents the mean \pm 1 S.E. of $(n)$ experiments of 1 killed control plant each; note that the low point of $\mathrm{pH}=7.6$ is based on a smaller sample. In all cases each plant is represented by the average of 6 tips assayed simultaneously. Based on data from Table 5. See Table 9 for ANOVA. 


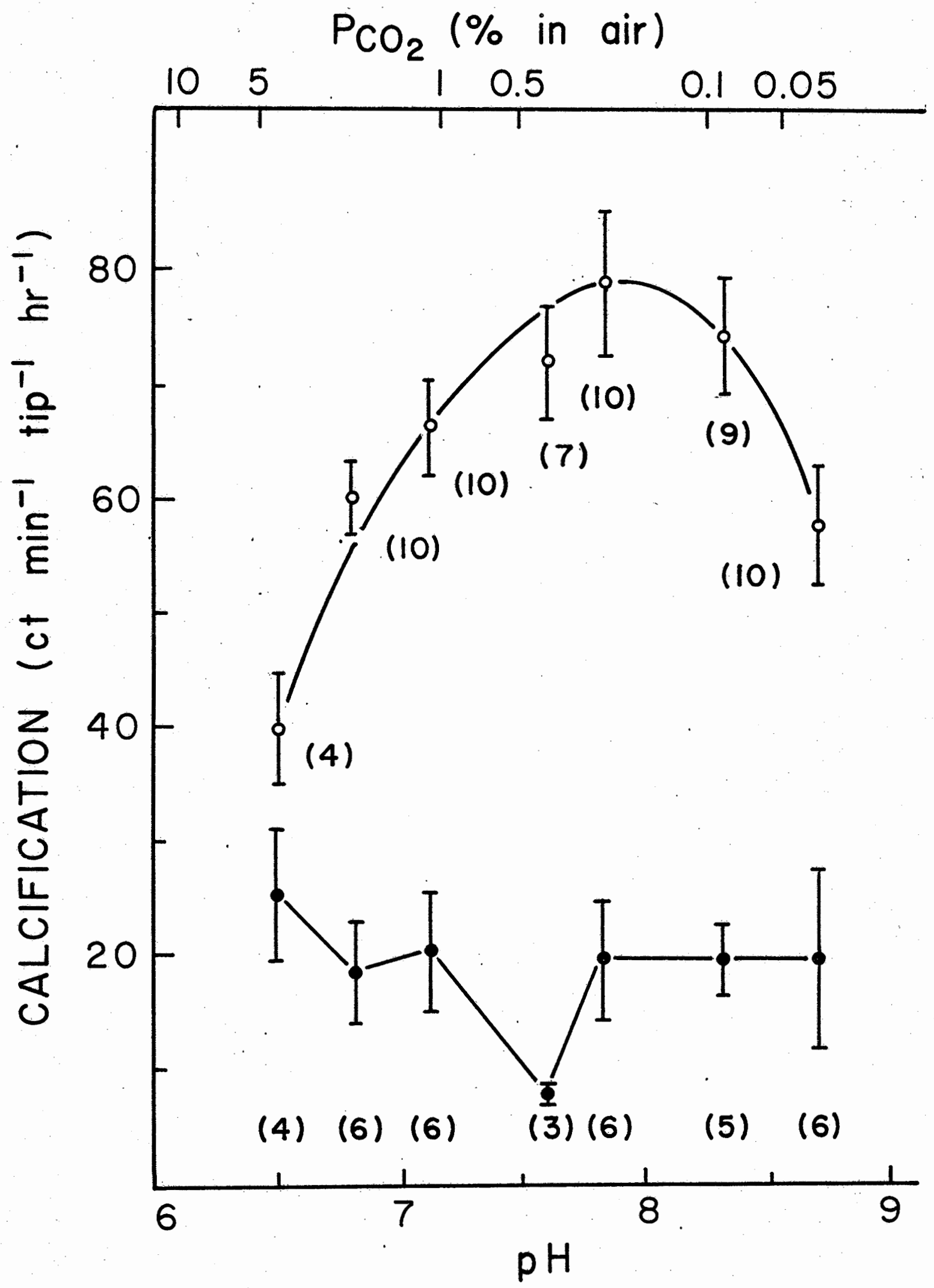


Figure 7. Composite of two experiments $\left(P_{\mathrm{CO}_{2}}=0.23 \%\right.$ and $\left.0.04 \%\right)$ in which $\mathrm{NaHCO}_{3}$ was added and one $\left(\mathrm{P}_{\mathrm{CO}_{2}}=0.04 \%\right)$ in which $\mathrm{Na}_{2} \mathrm{CO}_{3}$ was added to the sea water. Amounts added (millimolar incrementsl are given at the top of the figure. Open circles $(-0-)$ : mean \pm 1 S.E. of living plants. Closed circles $(-\infty): 1$ killed control plant. Each plant is represented by 6 tips assayed simultaneously. Triangles $\left(--\Delta^{-}\right)$: the portion of the standard-experiments curve (Fig. 6) that falls in this $\mathrm{pH}$ range. Experiment $\mathrm{B}-1$ (at far left) was incubated for 2 hrs, B-2 (in center) for 1.3 hrs, and $c-1$ (at far right) for 1.2 hrs. Each has been converted for comparative purposes to $1 \mathrm{hr}$, assuming linearity over time (see Pearse, 1972). Note that each point in this figure is based on only one experiment, in contrast to those in Fig. 6 . 


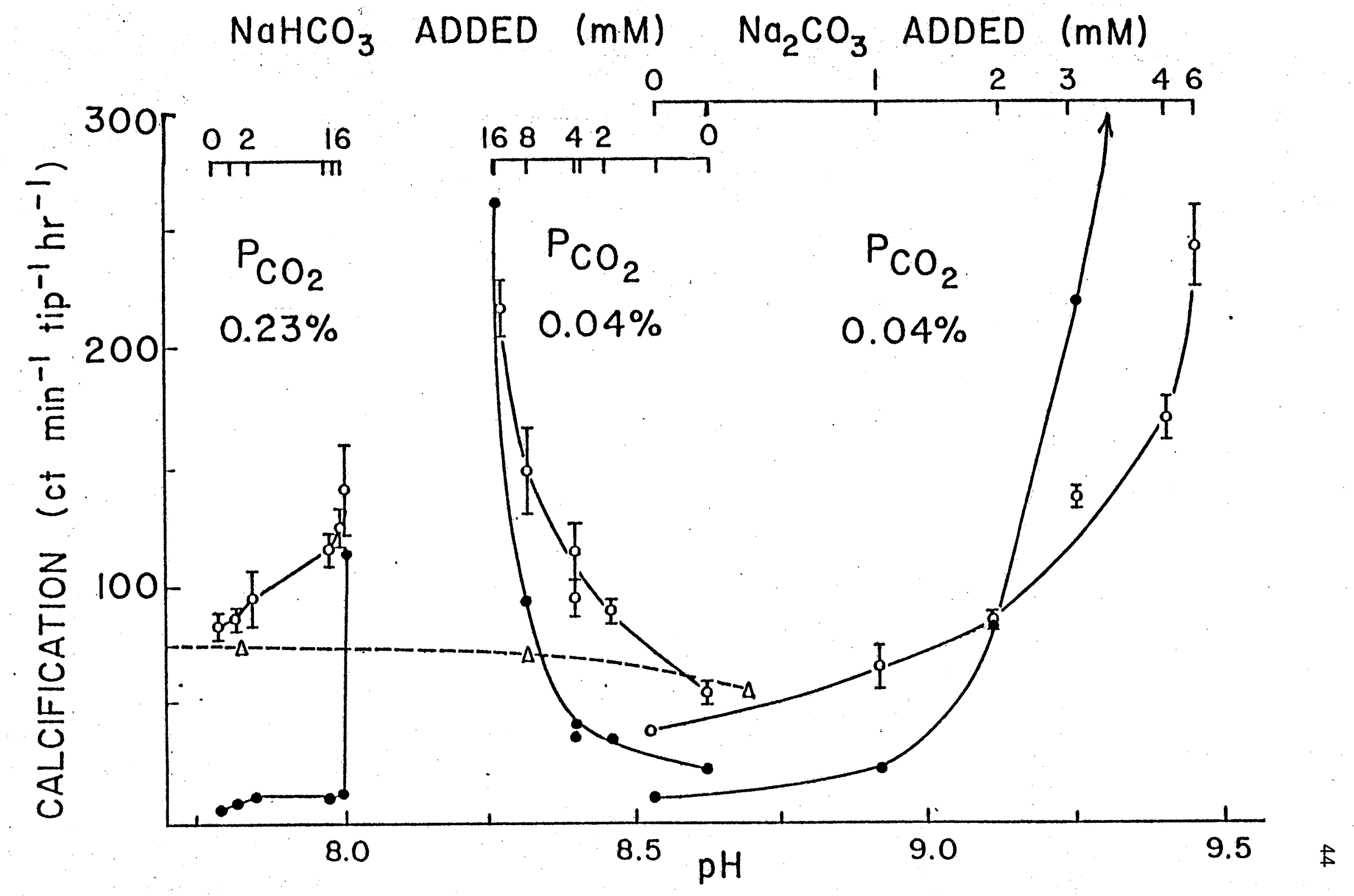




\section{LITERATURE CITED}

Adams, J.A.S., M.S.M. Mantovani, and L.L. Lundell. 1977. Wood versus fossil fuel as a source of excess carbon dioxide in the atmosphere: a preliminary report. Science 196:54-56.

Bolin, B. 1977. Changes of land biota and their importance for the carbon cycle. Science 196:613-615.

Borowitzka, M.A. and A.W.D. Larkum. 1976a. Calcification in the green alga Halimeda. 11. The exchange of $\mathrm{Ca}^{2+}$ and the occurrence of age gradients in calcification and photosynthesis. Jour. Exp. Bot. $27: 864-878$.

Borowitzka, M.A. and A.W.D. Larkum. 1976b. Calcification in the green alga Hal imeda. 111. The sources of inorganic carbon for photosynthesis and calcification and a model of the mechanism of calcification. Jour. Exp. Bot. 27:879-893.

Borowitzka, M.A. and A.W.D. Larkum. 1976c. Calcification in the green alga Halimeda. IV. The action of metabolic inhibitors on photosynthesis and calcification. Jour. Exp. Bot. 27:894-907.

Borowitzka, M.A. and A.W.D. Larkum. 1977a. Calcification in the green alga Halimeda. 1. An ultrastructure study of thallus development. Jour. Phycol. 13:6-16.

Borowitzka, M.A. and A.W.D. Larkum. 1977b. Algal calcification. To be published in: Oceanology and Marine Biology: Annual Review, Vol. 15.

Chalker, B.E. 1976. Calcium transport during skeletogenesis in hermatypic corals. Comp. Biochem. Physiol. 54A:455-459.

Clark, G.R., 11. 1976. Shell growth in the marine environment: approaches to the problem of marginal calcification. Amer. Zool. $16: 617-626$.

Clausen, C.D. 1972. Factors affecting calcification processes in the hermatypic corals Pocillopora damicornis and Porites compressa. Ph.D. Dissertation. Loma Linda Univ. $95 \mathrm{pp}$.

Coyne, L. 1975. Chemistry in natural water systems. Jour. of Chem. Ed. 52:796-800.

Crenshaw, M.A. 1964. Coccolith formation by two marine coccolithophorids, Coccolithus huxleyi and Hymenomonas sp. Ph.D. Dissertation. Duke Univ. $82 \mathrm{pp}$. 
Darley, W.M. 1974. Silification and calcification. Botanical Monographs No. 10. In W.D.P. Stewart (ed.). Algal Physiology and Biochemistry, pp-655-675. University of California Press, Berkeley and Los Angeles.

Darwin, C.R. 1842. The structure and distribution of coral reefs. London: Smith, Elder and Co. $214 \mathrm{pp}$.

Garrels, R.M., A. Lerman, and F.T. Mackenzie. 1976. Controls of atmospheric $\mathrm{O}_{2}$ and $\mathrm{CO}_{2}$ : past, present, and future. Amer. Sci. 64: 306-315.

Goreau, T.F. 1959. The physiology of skeleton formation in corals. 1. A method for measuring the rate of calcium deposition by corals under different conditions. Biol. Bull. 116:59-75.

Goreau, T.F. 1963. Calcium carbonate deposition by coralline algae and corals in relation to their roles as reef-builders. Ann. N.Y. Acad. Sci. 109:127-167.

Harvey, H.W. 1957. The chemistry and fertility of sea waters. Cambridge University Press, Cambridge. 234 pp.

Ikemori, M. 1970. Relation of calcium uptake to photosynthetic activity as a factor controlling calcification in marine algae. Bot. Mag. Tokyo 83:152-162.

Jolliffe, E.A. and E.B. Tregunna. 1970. Studies on $\mathrm{HCO}_{3}^{-}$ion uptake during photosynthesis in benthic marine algae. Phycol. 9:293-303.

Kolesar, P.T. 1973. Factors affecting the magnesium content of calcite secreted by some articulated coralline algae. Ph.D. Dissertation. University of California, Riverside. $131 \mathrm{pp}$.

Lucas, W.J. 1974. Photosynthetic fixation of ${ }^{14}$ Carbon by internodal cells of Chara corallina. Jour. Exp. Bot. 26:331-346.

Menard, H.W. 1964. Marine geology of the Pacific. McGraw-Hill Book Co:, New York. 271 pp.

Moss, D.N. 1976. Studies on increasing photosynthesis in crop plants. In R.H. Burris and C.C. Black (eds.). $\mathrm{CO}_{2}$ Metabolism and Plant Productivity, pp. 31-41. University Park ${ }^{2}$ Press, Baltimore.

Paasche, E. 1964. A tracer study of the inorganic carbon uptake during coccolith formation and photosynthesis in the coccolithophorid Coccolithus huxleyi. Physiologia Pl. Suppl . 3:1-82.

Paasche, E. 1965. The effect of 3-(p-chloropheny1)-1, 1-dimethylurea (CMU) on photosynthesis and light-dependent coccolith formation in Coccolithus huxleyi. Physiologia Pl. 18:138-145. 
Paasche, E. 1968. Biology and physiology of coccolithophorids. Ann. Rev. Microbiol. 22:71-86.

Park, P.K. 1969. Oceanic $\mathrm{CO}_{2}$ system: an evaluation of ten methods of investigation. Limnol. Oceanogr. 14(2):179-186.

Pearse, V.B. 1972. Radioisotopic study of calcification in the articulated coralline alga Bossiella orbigniana. Jour. Phycol. 8: 88-97.

Plass, G.N. 1956. Carbon dioxide and the climate. Amer. Sci. 44:302316.

Pytkowicz, R.M., S.E. Ingle, and C. Mehrbach. 1974. Invariance of apparent equilibrium constants with pH. Limnol. Oceanogr. 19: $665-669$.

Riley, J.P. and G. Skirrow (eds.). 1966. Chemical oceanography. Vols. 1 and 11. Academic Press, London. 710 and 508 pp.

Riley, J.P. and G. Skirrow (eds.). 1975. Chemical oceanography. Vols. 1 and 11 . 2nd ed. Academic Press, London. 606 and $648 \mathrm{pp}$.

Roth, A.A. 1974. Factors affecting light as an agent for carbonate production by coral. Geol. Soc. Amer. Abstr. 6(7):932.

Silva, P.C. 1957. Notes on Pacific marine algae. Madrono 14:41-51.

Skirrow, G. 1975. The dissolved gases - carbon dioxide. In J.P. Riley and G. Skirrow (eds.). Chemical Oceanography. 2nd ed. Vol. 1, pp. 1-192. Academic Press, London.

Smith, S.V. 1973. Carbon dioxide dynamics: a record of organic carbon production, respiration, and calcification in the Eniwetok Reef flat community. Limnol. Oceanogr. 18(1):106-120.

Smith, S.V. and D.W. Kinsey. 1976. Calcium carbonate production, coral reef growth, and sea level change. Science 194:937-939.

Smith, W.H., Jr. and D.W. Hood. 1964. pH measurement in the ocean: a sea water secondary buffer system. In Y. Miyake and T. Koyama (eds.). Ken Sugawara Festival Volume, Recent Researches in the Fields of the Hydrosphere, Atmosphere and Nuclear Geochemistry, pp. 185-202. Maruzen Co., Tokyo.

Stark. L.M., L. Almodovar; and R.W. Krauss. 1969. Factors affecting the rate of calcification in Halimeda opuntia (L.) Lamouroux and Hal imeda discoidea Decaisne. Jour. Phycol. 5:305-312.

Steemann Nielsen, E. 1975. Marine photosynthesis. American Elsevier Publ. Co., New York. 142 pp. 
Stoddart, D.R. 1969. Ecology and morphology of recent coral reefs. Biol. Rev. 44:433-498.

Suess, H.E. 1973. Natural radiocarbon. Endeavor 32:34-38.

Swift, E. and W.R. Taylor. 1966. The effect of $\mathrm{pH}$ on the division rate of the coccolithophorid Cricosphaera elongata. Jour. Phycol. 2: 121-125.

Thomas, C.M. 1976. Effects of temperature on calcium uptake in Bossiella orbigniana orbigniana. M.A. Thesis. Loma Linda Univ. $101 \mathrm{pp}$.

Vandermeulen, J.H., N.D. Davis, and L. Muscatine. 1972. The effect of inhibitors of photosynthesis on zooxanthellae in corals and other marine invertebrates. Mar. Biol. 16:185-191.

Whitfield, M. 1974. The ion massociation model and the buffer capacity of the carbon dioxide system in seawater at $25^{\circ} \mathrm{C}$ and 1 atmosphere total pressure. Limnol. Oceanogr. 19:235-248.

Wilbur, K.M., L.H. Colinvaux, and N. Watabe. 1969. Electron microscope study of calcification in the alga Halimeda (Order Siphonales). Phycol. 8:27-35. 


\section{APPENDIX}

The appendix contains the data from all 17 experiments. The first six rows represent the plants; the columns represent the treatments. Row 7 contains the treatment means.

The figures were derived using the equation:

$$
\text { Calcification (ct } \left.\min ^{-1} \operatorname{ip}^{-1} 2 \mathrm{hr}^{-1}\right)=\frac{10,000 \text { counts } \times \text { chamber corr. }}{6 \text { tips/planchet } \times \text { Exp. Corr. } \times}
$$

The chamber correction allowed for differences among treatments due to errors in addition of the isotope to each chamber. The experimental correction compensated for variation in incubation time, time between when experiment was run and the tips counted, and for Ca-45 decay of the ${ }^{45} \mathrm{CaCl}_{2}$ with time. Background counts $=11.5$ were subtracted. Six tips were counted simultaneously but each plant part was counted separately. See text for additional information. Note that the appendix figures are for 2 hrs. whereas the text data are for $1 \mathrm{hr}$. 
JULY 4, 1976, Experiment L-1

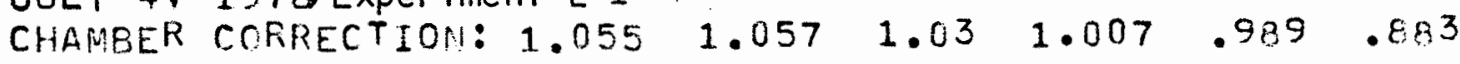
EXPERIMENT CORRECTION: 0.98970

\begin{tabular}{|c|c|c|c|c|c|}
\hline $\mathrm{mw} \mathrm{cm}^{-2}$ & $0.1 \mathrm{~mW} \mathrm{~cm} \mathrm{~cm}^{-2}$ & $0.4 \mathrm{~mW} \mathrm{~cm}$ & $1.3 \mathrm{~mW} \mathrm{~cm}$ & $2.3 \mathrm{ml}$ & $5 \mathrm{~mW}$ \\
\hline & 147.28 & 160.40 & 130.17 & 153 & 132 \\
\hline & & & 16 & $16 \varepsilon$ & \\
\hline & & & & & \\
\hline & & & & & 12 \\
\hline & & & & & .40 \\
\hline & & & & & .39 \\
\hline & 15 & 163.15 & 149.15 & 165.86 & 131.54 \\
\hline
\end{tabular}

JULY 12, 1976Experiment L-2

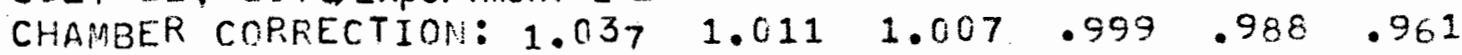
EXPERIMENT CORRECTION: 0.98117

$0 \mathrm{~mW} \mathrm{~cm}{ }^{-2} 0.8 \mathrm{~mW} \mathrm{~cm}-2.0 \mathrm{~mW} \mathrm{~cm}-1.2 \mathrm{~mW} \mathrm{~cm}^{-2} 5 \mathrm{~mW} \mathrm{~cm}{ }^{-2} 10 \mathrm{~mW} \mathrm{~cm}{ }^{-2}$

$\begin{array}{llllll}178.11 & 196.91 & 164.30 & 197.74 & 181.18 & 79.95\end{array}$

$\begin{array}{llllll}171.98 & 262.83 & 212.10 & 225.17 & 223.22 & 146.52\end{array}$

$\begin{array}{llllll}141.40 & 139.14 & 198.64 & 155.03 & 135.45 & 137.57\end{array}$

$\begin{array}{llllll}127.74 & 120.80 & 123.50 & 153.73 & 148.03 & 133.73\end{array}$

$\begin{array}{llllll}161.70 & 196.91 & 154.89 & 134.03 & 190.45 & 185.65\end{array}$

\begin{tabular}{lllllll}
219.97 & 199.47 & 170.27 & 20.5 .77 & 207.59 & 187.08 \\
\hline 166.82 & 186.01 & 170.61 & 178.58 & 180.98 & 145.08 \\
\hline
\end{tabular}

SEPTEMBEP 6, 1976, Experiment S-1

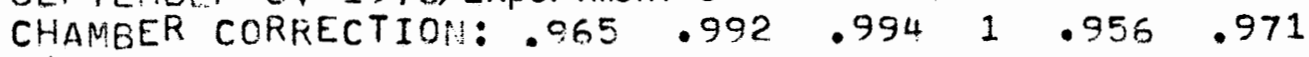

EXPERIMENT CORFECTION: 1.06060

\begin{tabular}{lrrrrr}
$0.04 \%$ & $0.11 \%$ & $0.23 \%$ & $0.39 \%$ & $0.93 \%$ & $2.26 \%$ \\
35.11 & 104.40 & 89.66 & 118.58 & 80.21 & 30.47 \\
90.61 & 111.14 & 108.28 & 136.05 & 94.89 & 95.72 \\
83.81 & 90.85 & 115.38 & 140.91 & 131.98 & 88.95 \\
71.00 & 130.34 & 151.37 & 111.07 & 139.78 & 90.15 \\
68.56 & 68.81 & 98.19 & 145.95 & 75.18 & 75.44 \\
66.66 & 148.54 & 156.09 & 161.37 & 151.26 & 122.81 \\
\hline 69.29 & 109.01 & 119.83 & 135.65 & 112.22 & 03.92 \\
\hline
\end{tabular}

OCTOBER 8, 1976, Experiment S-2

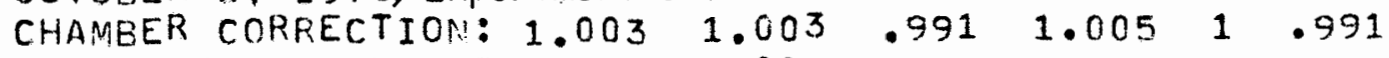

EXPERIMENT CORRECTION: 0.81900
$0.04 \%$
$0.11 \%$
$0.23 \%$
$0.39 \%$
$0.93 \%$
$2.26 \%$

155.12

156.35

113.21

154.36

168.42

133.58

85.00

198.27

170.01

150.94

182.67

136.02

108.63

164.30

161.30

162.55

110.94

102.75

114.88

173.71

172.16

170.45

174.51

149.57

$183.44 \quad 151.78$

182.59

1.74 .25

126.09

149.70

\begin{tabular}{rrrrrr}
83.43 & 165.83 & 142.21 & 175.27 & 107.50 & 109.47 \\
\hline 121.75 & 168.37 & 156.91 & 164.64 & 145.02 & 130.18 \\
\hline
\end{tabular}


NOVEMEER, 17,1976 , Experiment S-3

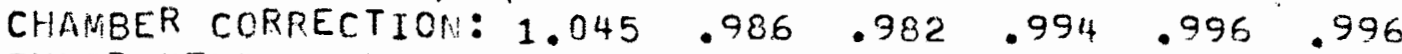

EXPERIMENT CORRECTION: 0.82900

\begin{tabular}{rrrrrr}
$0.04 \%$ & $0.11 \%$ & $0.23 \%$ & $0.39 \%$ & $0.93 \%$ & $2.26 \%$ \\
104.50 & 140.05 & 139.20 & 111.40 & 87.23 & 127.26 \\
76.92 & 152.87 & 173.70 & 158.86 & 126.02 & 125.83 \\
166.69 & 100.49 & 163.21 & 78.92 & 137.59 & 123.52 \\
130.45 & 173.93 & 140.95 & 134.90 & 159.35 & 115.87 \\
80.68 & 142.88 & 118.47 & 98.42 & 104.98 & 85.61 \\
127.91 & 213.50 & 163.36 & 180.65 & 83.31 & 147.29 \\
\hline 114.52 & 153.95 & 149.81 & 127.19 & 116.41 & 120.90 \\
\hline
\end{tabular}

NOVEMBEP 18,1976 , Experiment S-4

CHAMBER CORRECTION: $.987 \quad .994 \quad .972 \quad 1.044 \quad 1.012 \quad .99$

EXPERIMENT CORRECTION: 1.02400

\begin{tabular}{cccccr}
$0.04 \%$ & $0.11 \%$ & $0.23 \%$ & $0.39 \%$ & $0.93 \%$ & $2.26 \%$ \\
119.85 & 134.25 & 139.60 & 185.16 & 155.04 & 106.80 \\
130.66 & 108.78 & 207.31 & 155.74 & 141.29 & 111.22 \\
144.01 & 189.22 & 176.16 & 234.40 & 189.61 & 114.48 \\
125.45 & 172.13 & 223.57 & 188.40 & 117.68 & 102.13 \\
153.77 & 164.02 & 218.44 & 204.96 & 144.62 & 136.32 \\
142.81 & 127.37 & 217.77 & 143.25 & 150.30 & 85.33 \\
\hline 136.09 & 149.44 & 197.14 & 185.32 & 149.76 & 109.38 \\
\hline
\end{tabular}

NOV.27, 1976, Experiment $\mathrm{H}-1$

$\begin{array}{llllllll}\text { CHAMBER CORRECTION: } & 1.059 & .997 & .977 & .979 & .99 & .997\end{array}$

EXPERIMENT CORRECTION: 0.81629

\begin{tabular}{llrrr}
$0.04 \%$ & $0.11 \%$ & $0.23 \%$ & $0.39 \%$ & $1.05 \%$ \\
63.99 & 46.29 & 77.87 & 77.93 & 100.85 \\
35.66 & 48.26 & 65.96 & 38.06 & 149.56 \\
89.96 & 74.21 & 60.41 & 107.90 & 128.38 \\
46.51 & 37.86 & 34.93 & 40.95 & 50.84 \\
55.15 & 41.29 & 54.61 & 35.64 & 80.12 \\
57.36 & 84.65 & 65.57 & 83.09 & 95.78 \\
\hline 58.10 & 55.43 & 59.89 & 63.93 & 100.92 \\
\hline
\end{tabular}

DECEMBEP 12, 1976, Experiment C-1

CHAMBER CORRECTION: $.966 \quad .971 \quad .864 \quad 1.032 \quad 1.042 \quad 1.047$

EXPERIMENT COPRECTION: 0.50840

\begin{tabular}{lccccc}
$0 \mathrm{mM}$ & $1 \mathrm{mM}$ & $2 \mathrm{mM}$ & $3 \mathrm{mM}$ & $4 \mathrm{mM}$ & $6 \mathrm{mM}$ \\
81.20 & 136.34 & 139.40 & 193.29 & 296.79 & 325.00 \\
71.88 & 36.38 & 181.44 & 290.65 & 300.74 & 531.59 \\
97.96 & 182.59 & 226.91 & 339.81 & 409.70 & 496.24 \\
69.76 & 203.14 & 169.94 & 305.27 & 316.32 & 500.78 \\
96.06 & 145.38 & 170.18 & 286.31 & 409.18 & 617.13 \\
\hline 83.37 & 139.09 & 177.57 & 281.07 & 346.55 & 494.26 \\
\hline
\end{tabular}


DECEMBER 19, 1976, Experiment B-1

CHAMBER CORRECTIOH: $1.053 \quad 1.011 \quad 1.007 \quad .988 \quad .928 \quad 1.009$

EXPERIMENT CORRECTION: 0.82780

\begin{tabular}{cccccc}
$0 \mathrm{mM}$ & $1 \mathrm{mM}$ & $2 \mathrm{mM}$ & $4 \mathrm{mM}$ & $8 \mathrm{mM}$ & $16 \mathrm{mM}$ \\
155.30 & 191.24 & 219.15 & 242.22 & 203.50 & 269.09 \\
162.70 & 167.05 & 121.36 & 291.27 & 299.38 & 122.50 \\
129.74 & 174.39 & 280.64 & 239.98 & 292.80 & 304.93 \\
173.82 & 137.29 & 155.23 & 187.42 & 209.35 & 245.65 \\
182.82 & 206.43 & 196.23 & 239.66 & 229.58 & 380.67 \\
197.99 & 154.52 & 182.14 & 229.32 & 270.31 & 369.64 \\
\hline 167.06 & 171.82 & 192.46 & 238.31 & 250.82 & 282.08 \\
\hline
\end{tabular}

DECEMBER 27. 1976, Experiment S-5

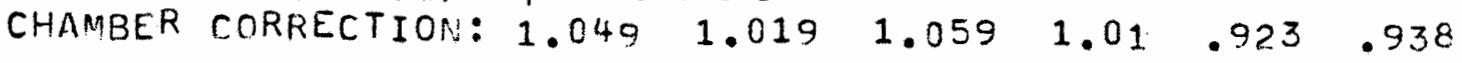

EXPERIMENT CORRECTION: 0.85790

\begin{tabular}{cccccc}
$0.04 \%$ & $0.11 \%$ & $0.23 \%$ & $0.39 \%$ & $1.05 \%$ & $2.26 \%$ \\
165.86 & 196.22 & 158.66 & 175.55 & 121.71 & 112.80 \\
112.76 & 135.90 & 146.03 & 131.93 & 108.68 & 103.54 \\
101.34 & 113.24 & 138.56 & 75.01 & 104.78 & 114.34 \\
117.23 & 130.81 & 128.17 & 127.07 & 160.91 & 93.65 \\
150.75 & 149.70 & 215.08 & 148.93 & 177.84 & 141.76 \\
161.64 & 157.41 & 250.24 & 138.16 & 121.52 & 128.24 \\
\hline 134.93 & 147.21 & 172.79 & 132.77 & 132.57 & 115.72 \\
\hline
\end{tabular}

DECEMBER 28, 1976, Experiment S-6

CHAMBER CORRECTION: $111.034 \quad .945 \quad 1.002 \quad 1.014 \quad 1.005$

EXPERIMENT CORRECTION: 0.81067

\begin{tabular}{rrrrrr}
$0.04 \%$ & $0.11 \%$ & $0.23 \%$ & $0.39 \%$ & $1.05 \%$ & $2.26 \%$ \\
89.92 & 17.22 & 106.60 & 92.59 & 71.72 & 73.80 \\
32.02 & 102.91 & 54.69 & 132.45 & 65.96 & 88.41 \\
92.02 & 140.66 & 136.01 & 189.87 & 114.31 & 154.45 \\
67.15 & 155.49 & 88.69 & 132.65 & 116.23 & 80.08 \\
73.98 & 147.85 & 110.00 & 94.79 & 172.01 & 89.09 \\
136.08 & 160.90 & 81.63 & 151.21 & 121.02 & 108.83 \\
\hline 81.86 & 120.84 & 96.27 & 132.26 & 110.21 & 99.11 \\
\hline
\end{tabular}

DECEMBER 29, 1976, Experiment B-2

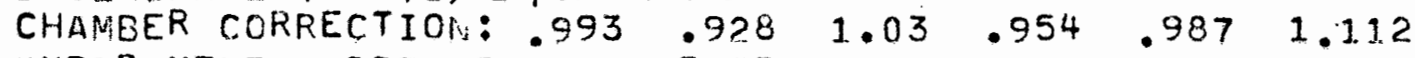

EXPERINENT CORRECTION: 0.50550

\begin{tabular}{cccccc}
$0 \mathrm{mM}$ & $2 \mathrm{mM}$ & $3 \mathrm{mM}$ & $4 \mathrm{mM}$ & $8 \mathrm{mM}$ & $16 \mathrm{mM}$ \\
98.07 & 144.92 & 133.44 & 214.46 & 186.56 & 418.31 \\
124.18 & 177.01 & 180.36 & 300.54 & 427.66 & 451.42 \\
102.37 & 182.76 & 177.69 & 234.81 & 351.28 & 446.70 \\
97.63 & 176.09 & 170.29 & 146.56 & 264.98 & 344.45 \\
155.45 & 206.89 & 246.74 & 181.58 & 248.42 & 431.29 \\
116.94 & 193.57 & 230.55 & 295.96 & 301.70 & 519.08 \\
\hline 115.77 & 180.21 & 189.84 & 278.98 & 296.76 & 435.22 \\
\hline
\end{tabular}


DECEMBER 30,1976 , Experiment S-7

CHAMBER CORRECTIOU: $1.013 \quad 1.023 \quad .987 \quad 1.013 \quad .965 \quad .993$

EXPERIMENT CORRECTION: 0.80790

\begin{tabular}{rrrrrr}
$0.04 \%$ & $0.23 \%$ & $0.39 \%$ & $1.05 \%$ & $2.26 \%$ & $5.45 \%$ \\
82.84 & 67.48 & 69.26 & 63.75 & 88.63 & 51.33 \\
96.27 & 129.47 & 104.25 & 99.36 & 90.38 & 48.92 \\
104.85 & 118.21 & 124.33 & 144.45 & 81.56 & 53.92 \\
94.41 & 120.40 & 99.94 & 162.64 & 131.00 & 38.07 \\
94.95 & 136.49 & 121.23 & 73.62 & 97.70 & 59.01 \\
99.30 & 126.79 & 170.62 & 159.93 & 151.01 & 58.79 \\
\hline 95.44 & 116.47 & 114.94 & 117.29 & 106.71 & 51.68 \\
\hline
\end{tabular}

JANUARY 23, 1977, EXPeriment $\mathrm{H}-2$

$\begin{array}{lllllll}\text { CHANBER CORRECTION: } & .983 & 1.016 & 1.022 & .973 & .995 & 1.01\end{array}$

EXPERIMENT. CORRECTION: 0.66830

\begin{tabular}{lrlrrr} 
TRIS & HEPES & CONTROL & \multicolumn{1}{c}{ TRIS } & \multicolumn{1}{l}{ HEPES } & $\mathrm{NaHCO}_{3}$ \\
92.02 & 56.87 & 161.76 & 55.64 & 74.90 & 315.19 \\
69.16 & 109.38 & 209.74 & 76.61 & 125.44 & 356.21 \\
54.36 & 88.53 & 175.22 & 80.24 & 98.39 & 293.07 \\
68.66 & 99.68 & 149.00 & 95.34 & 72.58 & 397.04 \\
65.27 & 109.38 & 134.64 & 49.69 & 103.16 & 458.43 \\
67.96 & 51.54 & 181.88 & 43.93 & 75.59 & 369.56 \\
\hline 69.57 & 85.89 & 168.70 & 66.91 & 91.68 & 363.25 \\
\hline
\end{tabular}

FEBRUARY 11,1977 , Experiment S-8

CHAMBER CORRECTION: $1.027 \quad 1.012 \quad .993 \quad .897 \quad 1.043 \quad 1.028$ EXPERIMENT COFRECTICN: 0.37910

\begin{tabular}{rccrrr}
$0.04 \%$ & $0.11 \%$ & $0.26 \%$ & $1.05 \%$ & $2.26 \%$ & $5.46 \%$ \\
81.59 & 133.84 & 165.60 & 71.17 & 115.76 & 62.29 \\
98.86 & 116.05 & 125.43 & 130.55 & 83.89 & 61.57 \\
147.48 & 126.15 & 156.60 & 151.05 & 145.42 & 107.99 \\
98.35 & 129.16 & 196.48 & 122.49 & 142.99 & 98.81 \\
140.06 & 144.93 & 163.61 & 141.29 & 155.18 & 77.67 \\
136.29 & 152.61 & 155.44 & 145.99 & 121.02 & 81.50 \\
\hline 117.10 & 133.79 & 160.53 & 127.09 & 127.38 & 81.66 \\
\hline
\end{tabular}

FEBRUARY 14,1977 , Experiment S-9

CHAMBER CORRECTION: .9741 .029

EXPERINENT CORRECTION: 0.67237

$1.011 \quad 1.016 \quad 1.025 \quad .945$

\begin{tabular}{rcccrr}
$0.04 \%$ & $0.11 \%$ & $0.26 \%$ & $1.05 \%$ & $2.26 \%$ & $5.46 \%$ \\
102.65 & 138.45 & 154.35 & 164.49 & 146.11 & 76.49 \\
142.67 & 160.14 & 175.51 & 146.09 & 113.35 & 71.12 \\
126.22 & 168.88 & 166.35 & 163.14 & 145.43 & 87.92 \\
155.58 & 216.44 & 181.86 & 187.90 & 167.93 & 83.79 \\
152.40 & 156.41 & 219.68 & 158.31 & 161.81 & 121.82 \\
128.37 & 156.30 & 197.85 & 1.76 .58 & 97.40 & 75.93 \\
\hline 134.65 & 166.10 & 182.60 & 166.08 & 138.67 & 86.18 \\
\hline
\end{tabular}


MARCH 21, 1977, Experiment S-10

CHAMBER CORRECTION: 1.0441 .031 .9911 .986 .948 EXPERIMENT CORRECTION: 0.61080

\begin{tabular}{rrrrrr}
$0.04 \%$ & $0.11 \%$ & $0.26 \%$ & $1.05 \%$ & $2.26 \%$ & $5.46 \%$ \\
153.73 & 169.18 & 163.45 & 140.09 & 118.09 & 74.72 \\
155.18 & 182.65 & 290.32 & 192.58 & 141.97 & 127.57 \\
142.90 & 187.73 & 165.06 & 162.52 & 127.97 & 84.23 \\
113.38 & 198.44 & 149.20 & 118.00 & 163.43 & 93.31 \\
228.08 & 295.62 & 310.85 & 243.27 & 179.31 & 74.04 \\
149.90 & 184.68 & 193.92 & 135.67 & 132.29 & 126.24 \\
\hline 157.20 & 203.05 & 212.13 & 165.35 & 143.84 & 36.68 \\
\hline
\end{tabular}

